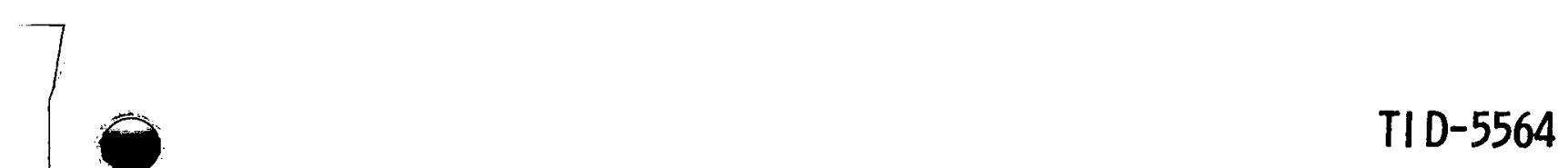

\title{
BIOLOGICAL BLAST EFFECTS
}

By

Clayton S. White

September 1959

[TIS Issuance Date]

Lovelace Foundation for Medical Education and Research

Albuquerque, New Mexico

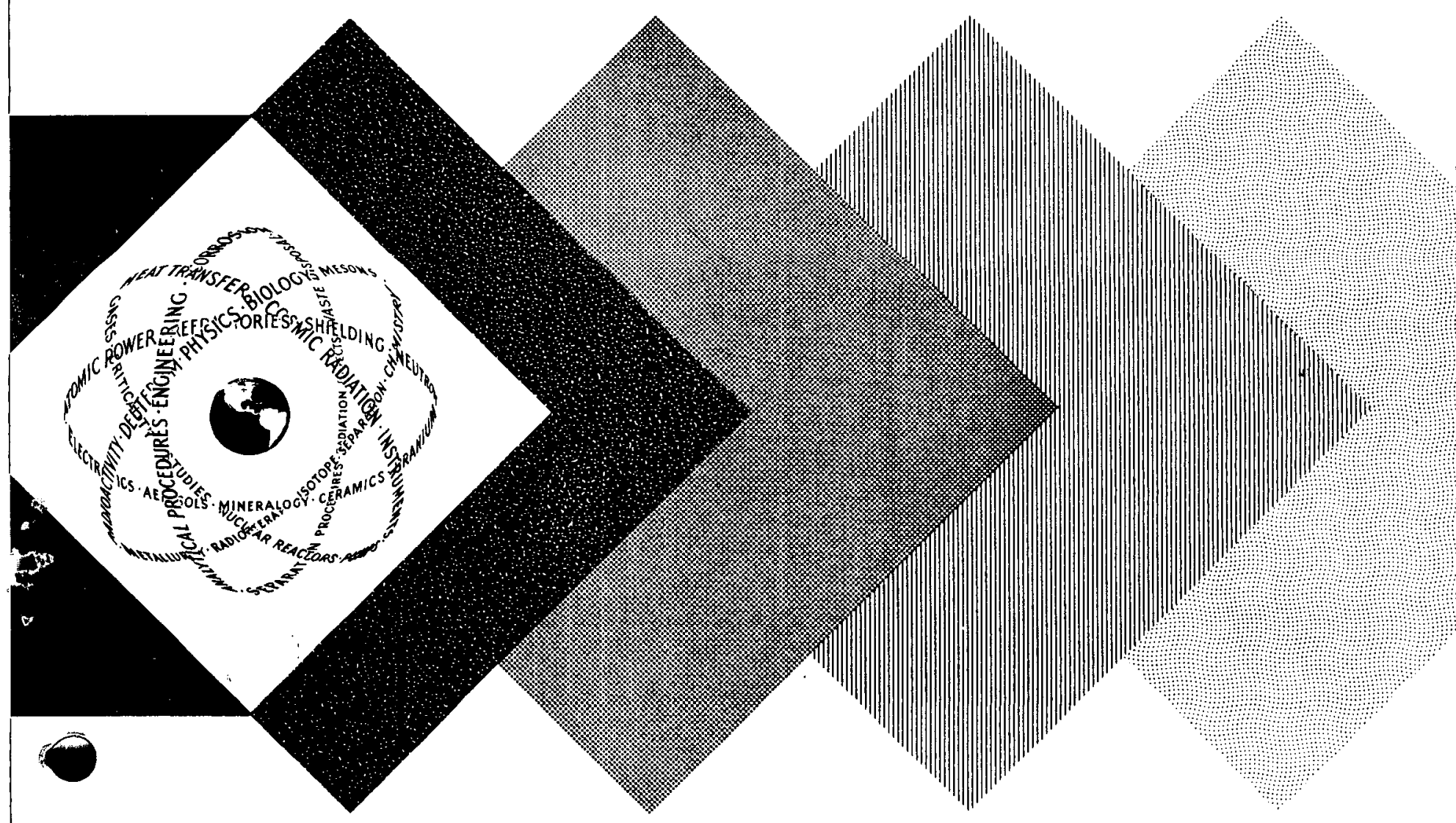

UNITED STATES ATOMIC ENERGY COMMISSION

Technical Information Service 


\section{LEG A L N O TICE}

This report was prepared as an account of Government sponsored work. Neither the United States, nor the Commission, nor any person acting on behalf of the Commission:

A. Makes any warranty or representation, expressed or implied, with respect to the accuracy, completeness, or usefuiness of the information contained in this report, or that the use of any information, apparatus, method, or process disclosed in this report may not infringe privately owned rights; or

B. Assumes any liabilities with respect to the use of, or for damages resulting from the use of any information, apparatus, method, or process disclosed in this report.

As used in the above, "person acting on behalf of the Commission" includes any employee or contractor of the Commission, or employee of such contractor, to the extent that such employee or contractor of the Commission, or employee of such contractor prepares, disseminates, or provides access to, any information pursuant to his employment or contract with the Commission, or his employment with such contractor.

This report has been reproduced directly from the best available copy.

Printed in USA. Price \$0.50. Available from the Office of Technical Services, Department of Commerce, Washington 25, D. C.

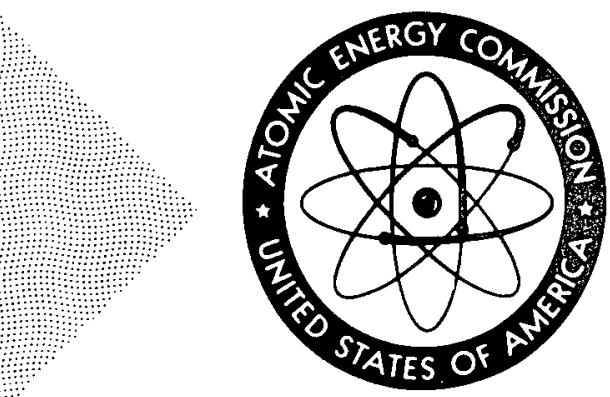




\section{DISCLAIMER}

This report was prepared as an account of work sponsored by an agency of the United States Government. Neither the United States Government nor any agency Thereof, nor any of their employees, makes any warranty, express or implied, or assumes any legal liability or responsibility for the accuracy, completeness, or usefulness of any information, apparatus, product, or process disclosed, or represents that its use would not infringe privately owned rights. Reference herein to any specific commercial product, process, or service by trade name, trademark, manufacturer, or otherwise does not necessarily constitute or imply its endorsement, recommendation, or favoring by the United States Government or any agency thereof. The views and opinions of authors expressed herein do not necessarily state or reflect those of the United States Government or any agency thereof. 


\section{DISCLAIMER}

Portions of this document may be illegible in electronic image products. Images are produced from the best available original document. 


\title{
BIOLOGICAL B LAST EFFECTS
}

\author{
Remarks by \\ Clayton S. White, M. D.
}

Presented before

The Special Subcommittee on Radiation

of the

Joint Committee on Atomic Energy

during Public Hearings on

The Biological and Environmental Effects of Nuclear War

Washington, D. C.

24 June 1959

Progress Report

AEC Contract No. AT $(29-1)-1242$

Lovelace Foundation for Medical Education and Research Albuquerque, New Mexico 


\title{
BIOLOGICAL BLAST EFFECTS
}

\author{
Remarks by \\ Clayton S. White, M.D. \\ Lovelace Foundation for Medical Education and Research \\ Albuque rque, New Mexico \\ June, 1959
}

Introduction

This presentation, though generally concerned with biological effects of airborne blast phenomena, will be limited to deal briefly with three main topics. First, the scope and nature of the several blast hazards will be delineated. Secondly, tentative criteria for threshold damage to humans will be set forth. Thirdly, these criteria will be related to nuclear weapons in terms of ground ranges and areas involved for $1 \mathrm{MT}$ and $10 \mathrm{MT}$ surface detonations, and to allow appreciation of the relative importance of blast with other effects, appropriate values for ionizing and thermal radiation will be noted.

Scope and Nature of Blast Hazards

General

Blast injury to a biological target, including man, depends primarily upon (a) the pressure pulse that emanates from an explosion in soil, water or air, (b) the mass movement of material surrounding the explosion which, in the case of air detonations, involves blast winds that accompany the pressure variations, and (c) the consequences of the interaction of these phenomena with the target and its immediate environment. All of these factors vary in magnitude and duration as dictated by a variety of circumstances among which are type and weight of explosive and range from the detonation.

Scope

For the purposes of discussion it is helpful to distinguish four categories of air blast damage to biologic media defined as follows $(1,2)$ :

1. Primary blast effects include injuries caused by variations in environmental pressure which follow an explosion due both to the primary pulse and its reflections from structures or objects 
near the biological target. These pressure variations are customarily measured in pounds per square inch (psi) either above or below the pressure existing prior to the detonation.

Biologic damage depends upon a variety of factors, including the rate, character and magnitude of the pressure rise and fall and the duration of the several segments of the pressure pulse.

2. Secondary blast injuries a re those which follow the impact of penetrating and nonpenetrating missiles energized by blast winds.

Important in "fixing" the hazard to animais and man are missile velocity, mass, size, shape, composition, and density, along with the specific regions and tissues of the body involved in the traumatic experience $(3,4,5,6)$.

3. Tertiary blast effects incorporate damage which is a consequence of physical displacement of the biologic target by blast shock and winds.

The seriousness of the problem depends upon the magnitude of the accelerative "load" imposed on the total organism and its several parts, the decelerative experience - particularly when violent impacts with solid surfaces are involved and the portions and areas of the body concerned. Thus, the time-history of displacement both during acceleration and deceleration are important. However, a less precise parameter - veiocity at impact - is actually quite us eful and has the virtue of simplicity.

4. Miscellaneous effects of blast, biologically, can involve exposure to ground shock; dust, whether arising from the earth's surface or the walls of inhabited structures; and temperature phenomena - other than those related to thermal radiation per se - such as compression and aerodynamic heating, contact with hot dust and debris and conflagration heat from blastproduced fires. 


\section{Nature of Blast Injuries}

Since blast injuries and related problems have been extensively studied and described (1-4, 7-55) and applicability of the data to long duration overpressures and to displacement and missile hazards directly related with nuclear blast has to some extent been explored (1-4,44-55), only a cursory summary of pathology will be detailed here.

\section{Primary Blast}

With regard to pressure-related phenomena, as a general rule, one can say damage is most marked in those regions wherein there exists the greatest variation in tissue density and, particularly, in the air-containing organs of the body. A corollary of these facts is that the air-containing organs, their nearby tissues and the junction of the ribs and soft tissues are sensitive indicators of blast damage; e.g., the eardrum, the sinuses and lung.

The most dangerous lesion, usually associated with fatality within a few minutes, involves lung damage resulting in "air" bubbles reaching the general circulation, including the vessels of the heart and brain. Also, suffocation from lung hemorrhage and edema with heart failure from lack of oxygen and high concentrations of carbon dioxide can occur early. Brwising and bleeding of the lung, if untreated, can result in serious pneumonic infections in humans. Too, unless cases with lung hemorrhage can be kept at rest, recurrence of bleeding is a frequent and quite serious complication. Bruising of the heart, the liver, spleen and abdominal organs, with areas of hemorrhage and sometimes rupture of the hollow viscera occur. Late complications from perforation peritonitis, pneumonia with lung abscess and areas of degeneration in the central nervous system require careful and prolonged care.

One new (57) lesion, discovered by Richmond recently, involves fracture of the thin bones separating the paranasal sinuses from the orbit. The finding was observed during shock tube exposure of animais to pressure conditions realistically*simulating nuclear blast.

Missiles

Missiles which penetrate into major body cavities and damage critical organs, such as the heart, liver, spleen, other abdominal organs, the eyes 
and brain, are similar to the ballistic problems associated with war casualties (5, 6, 58-64). Many of these require early surgery to avoid fatalities, appropriate care for fractures and prolonged treatment to handle infections of major body cavities and deep lacerations.

Nonpenetrating missiles impacted against the chest can produce bilateral lung lesions very similar to those of primary blast with early fatality (64). Skull fracture, concussion, rupture and hemorrhage of the liver and spleen, and skeletal fracture can be very dangerous as can crushing injuries from heavy masses of masonry and other building materials (65-73).

\section{Displacement}

Damage from displacement can be of two general types. One type involves differential displacement of different portions of the body - loss of a hand or limb, for example. The other type occurs from total displacement of the entire organism with the decelerative experience being the most hazardous. The trauma which occurs can be similar to automobile and aircraft accidents and, in type and required treatment, poses only a few problems of an unusual nature. However, the hazards of violent impact are of considerable importance in the case of nuclear explosions because of the great range and long duration of the blast winds $(1,49-53,65,67-79)$.

\section{Miscellaneous Effects}

The nature of damage from ground shock concerns trauma from displacement and impact with heavy objects as has been noted above.

Sufficiently high concentrations of dust under certain circumstances has proved fatal to man simply through deposit in, and obstruction of, the small airways of the lung (80). The danger depends upon time of exposure and the concentration of appropriately sized dust particles. Studies inside blast protective shelters at the Nevada Test Site indicate there need be no serious hazard to occupants providing the inside walls of structures are not finished with dust-producing materials (54).

Thermal problems can involve burns from other than thermal radiation, but these qualitatively are similar to the latter and others appearing before the Committee will deal with the injuries involving exposure to heat. 


\section{Combined Effects}

In practice it is not the rule to observe primary, secondary or tertiary blast effects alone. Indeed, in a nuclear explosion these will be seen in all possible relationships, plus damage from ionizing and thermal radiation. It is instructive, however, to call attention to the Texas City Disaster of 16 and 17 April 1947, which has been well documented both from the physical (81) and medical points of view $(39-42)$.

Figures 1 and 2 show missile damage to a grain elevator and oil storage tanks (81). Figure 3 depicts the inside of an industrial installation after the explosion, and gives some suggestion of the hazardous debris created by the blast (81). Figure 4 shows one type of injury from glass to an engineer sitting at a desk with his right side turned toward a window a few feet away (39). This man was blown under a table, was completely "blinded" by flying glass, and was dazed but not unconscious. He noted chest pain, coughed blood intermittently for a week and suffered the following injuries: penetrating wound of the right eye with prolapse requiring evisceration; multiple lacerations of the right side of the face with severance of the facial nerve and parotid duct; lacerations of the neck, eyelids, left deltoid region and both lower extremities; perforation of the right eardrum and blast injury to the lung (39).

Two other cases are quoted from the report of Drs. Virginia and T.G. Blocker (39).

"Case V. N.B., a colored female, aged thirty-seven, was standing out in the open near the Seatrain with her left side turned toward the ship. She felt the blast and saw debris flying through the air in all directions before she was knocked unconscious by a flying missile. When she 'came to', she was in water up to her waist and part of her clothes had been blown off. The patient was approximately two months pregnant at the time, and within an hour had an inevitable abortion without complication. Injuries sustained were (1) severe laceration of the ieft leg; (2) lacerations of the scalp; (3) mild head injury; (4) perforation of the left eardrum; (5) spontaneous abortion; and (6) minor abrasions and contusions.

"Case VII. S.R., a colored male, aged thirty-nine, had just come 
from loading flour on the High Flyer and was standing at the end of Pier $O$ facing the burning ship. When the explosion occurred, he was thrown upward so high that he could see over Warehouse $O$; he was then blown laterally into the water near the Seatrain installation. He did not lose consciousness and was able to swim to land. Most of his clothes were blown off. Injuries sustained were (1) perforation of both eardrums; (2) severe scalp lacerations; (3) severe laceration of left upper arm with extensive infection; (4) left ulnar paralysis; and (5) laceration of right foot."

Figure 5 summarizes various types of injuries involved in the Texas City experience in which about 560 persons were killed or missing, 800 cases hospitalized and between 3,000 and 4,000 other less serious casualties occurred (39). The disaster illustrates very well the catastrophic character and nature of blast injuries and, if multiplied several fold, illustrates many of the biomedical consequences of large scale nuclear blast delivered to an unprotected urban or suburban area.

Tentative Criteria for Threshold Damage

A few selected quantitative data regarding the environmental conditions which define gross biological hazards will now be noted as background for fixing tentative threshold criteria for blast damage to humans. The objective is to estimate conditions likely to be at, or near, those which will just cause casualties, with a casualty defined simply as a person sufficiently injured to be unable to care for himself and thus become a burden to someone else. Information relevant to the primary, secondary, and tertiary problems will be set forth separately below.

\section{Primary Effects}

In general, it can be said that (a) mammalian material tolerates slowly rising overpressures much better than those developing almost instantaneously, and (b) overpressures of long duration are likely to be more damaging than pressure pulses of short duration.

Fisher, Krohn and Zuckerman $(37,38)$ in an excellent study at Oxford University, using high explosives and pressure pulses from 1 to $3 \mathrm{msec}$ in 
duration, have shown that the overpressures required to fatally injure 50 per cent $\left(\mathrm{P}_{50}\right)$ of mice, guinea pigs, rabbits, monkeys and goats were near $27,32,55,100$ and $200 \mathrm{psi}$, respectively. The figures could be related to the weight of the animals by the equation

$$
P_{50}=0.24 \mathrm{w}^{2 / 3}+23.7
$$

where

$$
\begin{aligned}
& P_{50}=\text { local static overpressure in psi } \\
& W=\text { body weight in gms }
\end{aligned}
$$

The authors solved this equation for the 60 and $80 \mathrm{kgm}$ man and predicted human tolerance to "short"-duration, high explosive generated overpressures would be 390 and 470 psi for 50 per cent mortality, respectively. The same authors from field studies in bombed cities in England noted 12 human exposures for which the estimated overpressures ranged from 170 to 500-600 psi. There was one fatality related with $450 \mathrm{psi}$. Ten individuals survived from 170-450 psi and the other was not killed at between 500-600 psi.

These estimates of human tolerance did not contradict the observations of Desaga in Germany (9) who noted two deaths among 13 men exposed to high explosive bombs. The estimated maximal overpressure was 235 psi which resulted from an incident pressure of $58 \mathrm{psi}$ reflecting from the corner walls of an open-topped, concrete, gun emplacement where the men were located. Desaga (9) further noted that man's tolerance to high explosive blast was similar to that of the large dog for which he noted just fatal conditions as follows : 
Table 1

"Fast"-rising "Short"-duration Overpressures Required for Near 100 Per Cent Mortality in Dogs

\begin{tabular}{cc}
$\begin{array}{c}\text { Max Static } \\
\text { Overpressure } \\
\text { psi }\end{array}$ & $\begin{array}{c}\text { Overpressure } \\
\text { Duration } \\
\text { msec }\end{array}$ \\
\hline 216 & 1.6 \\
218 & 1.6 \\
125 & 4.1 \\
85 & 8.6 \\
79 & 10.3 \\
76 & 11.8 \\
\hline
\end{tabular}

Clemedson (24) using mice in a shock tube study, confirmed the effect of duration on mortality, which data were also consistent with the opinions of Hooker who worked many years earlier in the United States (10).

Observations at the Nevada Test Site in 1953 revealed rather severe though non-fatal injuries to dogs exposed to nuclear-produced pressure pulses in open blast protective shelters at maximal overpressure between 12 and $25 \mathrm{psi}$, but enduring for from 500 to almost $800 \mathrm{msec}$. Too, the re were findings indicating that the rate of pressure rise was of importance.

At the time, the Nevada experience seemed inconsistent with the earlier high explosive blast results, but it is now known from subsequent work in the field $(1,2,49,50)$ and in the laboratory $(2,55,56)$ that studies of the effects of long duration overpressures simply extend the high explosive data. However, to date, the gap between the short duration high explosive work and the long duration field and shock tube investigations has not been filled, though appropriate experiments are now under way in Albuquerque.

The most recent experiments involving overpressures ranging from 80 : to much over $1,000 \mathrm{msec}$ in duration $(56,82)$ were carried out in a shock tube with four species of animals and represent the best data available for estimating human tolerance to long duration overpressures. Animals were exposed in cages bolted to a metal plate closing the end of the shock tube 
and hence the incident and the reflected overpressures were applied almost simultaneously. To show the incident and reflected pressures associated with 1, 50 and 99 per cent mortality, Table 2 was prepared.

Table 2

Shock Tube Mortality Data for "Fast"-rising Long Duration Overpressures When Incident and Reflected Pressures Are Applied Almost Simultaneously.

\begin{tabular}{|c|c|c|c|c|c|c|}
\hline \multirow{3}{*}{$\begin{array}{l}\text { Animal } \\
\text { Species }\end{array}$} & \multicolumn{6}{|c|}{ Overpressure in psi for indicated mortality } \\
\hline & \multicolumn{2}{|c|}{$1 \%$} & \multicolumn{2}{|c|}{$50 \%$} & \multicolumn{2}{|c|}{$99 \%$} \\
\hline & Incident & Reflected & Incident & Reflected & Incident & Reflected \\
\hline Mouse & 7 & 20 & 11 & $2.9 .8 \pm 1.1$ & 15 & 44 \\
\hline Rabbit & 9 & 25 & 12 & $33.4 \pm 1.2$ & 15 & 44 \\
\hline Guinea pig & 10 & 28 & 13 & $36.7 \pm 0.7$ & 17 & 48 \\
\hline Rat & 10 & 28 & 14 & $38.7 \pm 0.6$ & 18 & 53 \\
\hline $\operatorname{Man} *$ & & $20=35$ & & $40-50$ & & $55-65$ \\
\hline
\end{tabular}

* Tentative estimate.. Data.AEC Project, Lovelace Foundation, Albuque rque, New Mexico.

The reader will note that Table 2 contains a tentative estimate of human tolerance which applies only to "fast"-rising, "long" duration pressure pulses. Too, it is important to understand that the pressures estimated for beginning mortality - 25-35 psi - can arise in two ways. First, in case an individual were close to a reflecting: surface an incident pressure ranging from about 8 to 12 psi can reflect to $25-35$ psi. In such a case the maximal pressure of 25-35 psi is applied almost instantaneously.

Secondly, an individual in the open or in a large building could be exposed to an incident pressure near 25-35 psi and in such a case a maximal pressure of this value would also be applied almost instantaneously. This point is emphasized because the pressures usually. quoted in weapons effects manuals applies to incident, "free-field". pressures. It is necessary to specify tolerance in terms of the maximal, fast-rising pressure and to know that this can involve (a) an incident pressure which is maximal, or (b) a much lower incident pres - 
sure which reflects to the maximal pressure specified. In terms of range from a nuclear detonation this distinction can involve a considerable variation in distance.

In passing, this point can be emphasized further by noting that if the cage of the guinea pig, for example, is mounted $1 \mathrm{ft}$ from, instead of against the reflecting plate of the shock tube, the maximal or reflected pressure which is fatal to 50 per cent of the animals is quite different (56); e.g., about 58 compared with 37 psi maximal (reflected) overpressure. In the case of the higher tolerance the animal was first exposed to the incident pressure and about $1.4 \mathrm{msec}$ later to the reflected or max pressure. Table 3 summarizes the situation for emphasis.

Table 3

Comparison of the Incident and Reflected Long-Duration Overpressures Fatal to 50 Per Cent of Guinea Pigs Exposed in a Shock Tube Against and 1 Foot from a Reflecting Surface

\begin{tabular}{|c|c|c|}
\hline $\begin{array}{l}\text { Location } \\
\text { of cage }\end{array}$ & $\begin{array}{l}\text { Overpressure in psi } \\
\text { for } 50 \text { per cent mortality } \\
\text { incident reflected }\end{array}$ & $\begin{array}{l}\text { Time interval in msec } \\
\text { between incident and } \\
\text { reflected pressure } \\
\end{array}$ \\
\hline Against end-plate & $36.7 \pm 0.7$ & Essentially none \\
\hline $1 \mathrm{ft}$ from end-plate & $57.1 \pm 1.1$ & 1.36 \\
\hline
\end{tabular}

With regard to estimating a threshold for human damage to long-duration overpressure based on lung damage, it can be said that slight lung hemorrhage has been noted in mice, rabbits, rats and guinea pigs exposed in a shock tube against a reflecting surface to an incident overpressure of about 6 psi which reflected to near $15 \mathrm{psi}$. Consistent with this, an incident pressure of approximately 8 psi is known to have produced lung hemorrhage in a dog exposed in front of a reflecting surface to full-scale nuclear blast (53).

'Thus; on' the basis of the few animal data available on sharp-rising, long-duration pressure pulses, it is felt that human lung damage will occur in minimal form under circumstances which involve (a) an "open"l exposure to $15 \mathrm{psi}$ incident, or (b) exposure to $6 \mathrm{psi}$ incident in a location where reflections to $15 \mathrm{psi}$ max could occur almost immediately after arrival of the incident overpressure. 
In case one desires to use the response of the more sensitive eardrum as a criteria in estimating the tolerance of man to blast, there are also uncertainties because the response of the human tympanic membrane to blastproduced overpressure is not known at all precisely. However, the classical study of Zalewski in 1906 (83) is helpful. Using human cadavers, this inves tigator applied slowly increasing pressures to the external auditory meatus until rupture of the eardrum occurred. Data are summarized in Table 4.

\section{Table 4}

Pressures Required to Rupture the Eardrums of Human Cadavers and Dogs when Pressure was Applied Within 24 Hours After Death (83)

\begin{tabular}{lccccc}
\hline \multirow{2}{*}{$\begin{array}{c}\text { Species } \\
\text { Studied }\end{array}$} & $\begin{array}{c}\text { No. of } \\
\text { cases }\end{array}$ & $\begin{array}{c}\text { Age } \\
\text { group }\end{array}$ & \multicolumn{3}{c}{$\begin{array}{c}\text { Pressures required to rupture } \\
\text { tympanic membranes in psi }\end{array}$} \\
\hline \multirow{2}{*}{ Human } & 19 & $1-10$ & 20.9 & 43.2 & 33.1 \\
& 15 & $11-20$ & 6.0 & 44.1 & 25.5 \\
& 15 & $21-30$ & 15.3 & 29.6 & 20.5 \\
& 17 & $31-40$ & 6.4 & 35.4 & 23.2 \\
& 11 & $41-50$ & 16.8 & 31.5 & 20.7 \\
& 12 & $51-60$ & 13.5 & 38.3 & 21.0 \\
& 14 & $61-70$ & 5.4 & 31.5 & 18.8 \\
& 8 & Above 70 & 16.2 & 26.5 & 20.7 \\
\hline \multirow{2}{*}{ Total } & 111 & Average & 5.4 & 44.1 & 22.9 \\
\hline Dogs & 10 & Not stated & 9.1 & 22.8 & 14.9 \\
\hline
\end{tabular}

The average pressure required to rupture the human eardrum varied with age from about 33 psi for the first decade of life to near 20 psi for the older age groups. However, the lowest and highest pressures for rupture wère 5.5 and 44.1 psi, respectively. Dogs-(age not stated) similarly studied by Zalewski revealed pressures for rupture ranging from about 9 to 23 psi with a mean of 15 psi: Exposure of young dogs to nuclear blast at the Nevada Proving Grounds $(1,50)$ indicated that the maximal pressures for rupture of the eardrum ranged from 4.1 to 85.8 , with 31.2 psi being the statistically determined pressure required for 50 per cent failure of the tympanic membrane (50). The highest overpressure without rupture was noted to be $66.6 \mathrm{psi}$. 
Apparently the bast data for young dogs are fairly close to the laboratory results obtained on human material. Too, the studies of $Z$ uckerman (43) noting human field data in bombed British cities are reasonably consis tent with the material presented previously.

On a tentative basis, therefore, it seems reasonable to believe that human eardrum failure begins at near 5 psi maximal which can be either an incident or reflected overpressure. In case of the latter, about $2.5 \mathrm{psi}$ is close to the incident pressure which will reflect to 5 psi under appropriate conditions.

Human response to slowly rising overpressures of both short and long duration is not known. However, it has been demonstrated that dogs are much more tolerant to long-duration pressures rising to a maximum in from 20 to $150 \mathrm{msec}(48)$ than they are to sharp-rising pulses. Eardrum failure; damage to the sinus membranes and fracture of the thin orbital bones do occur, though lung damage is markedly minimized for the slower rising overpressures. Further details need not be given here since the present objectives a re directed to setting thresholds involving the minimal overpressure which is likely to cause human casualties.

\section{Secondary Effects}

The physical and biological factors that determine the seriousness of human injury from objects striking the surface of the body - whether or not they penetrate skin tissues and bone - are complex indeed. Ignoring most of these, and for the sake of brevity, the missile problem will be limited and simplified here by using only impact velocity and missile mass to illustrate the just threshold conditions for penetration into a major body cavity of a dog and for nonpenetrative fracture of the human skull.

Table 5 gives the data of Bowen; et al. (4) obtained by firing irregular: ". glass missiles against the abdominal wall of dogs, and in terms of missile mass and impact velocity, defines conditions for expecting glass missiles to pierce the body wall and enter the abdominal cavity 1, 50 and 99 per cent of the time. 
Table 5

The Velocity-Mass-Probability Relationships Required for Small Window Glass Fragments to Traverse the Abdominal Wall and Reach the Peritoneal Cavity of Dogs*

\begin{tabular}{cccc}
\hline $\begin{array}{c}\text { Mass of } \\
\text { glass fragment } \\
\text { gms }\end{array}$ & \multicolumn{3}{c}{$\begin{array}{l}\text { Impact velocities in } \mathrm{ft} / \mathrm{sec} \text { for indicated } \\
\text { probabilities of penetration in per cent }\end{array}$} \\
\hline 0.05 & $1 \%$ & $50 \%$ & $99 \%$ \\
0.1 & 320 & 570 & 1000 \\
0.5 & 235 & 410 & 730 \\
1.0 & 160 & 275 & 485 \\
10.0 & 140 & 245 & 430 \\
\hline
\end{tabular}

* Data from Bowen, et al., AECU-3350

The reader will note that a $10 \mathrm{gm}$ glass fragment, having a velocity of $115 \mathrm{ft} / \mathrm{sec}$ has only a 1 per cent probability of traversing the abdominal wall of a dog. Since clothing will degrade the velocity of small missiles moving relatively slowly, and because of the less serious nature of skin and tissue lacerations, an impact velocity of $115 \mathrm{ft} / \mathrm{sec}$ for a $10 \mathrm{gm}$ glass fragment has been a rbitrarily chosen as the threshold for human casualties from glass and other frangible materials. Such a decision may well have to be modified later, since a quantitative study of eye injury from glass and other small irregular missiles has not yet been done. However, the $10 \mathrm{gm}-115 \mathrm{ft} / \mathrm{sec}$ criteria is strengthened somewhat by the data of Journee (5) who noted that spherical bullets weighing $8.5 \mathrm{gm}$ only produced a contusion of the skin when fired at human cadavers at velocities up to $150 \mathrm{ft} / \mathrm{sec}$, whereas a velocity of $128 \mathrm{ft} / \mathrm{sec}$ for 6 to $12 \mathrm{~mm}$ caliber rifle bullets was set as the lower limit at which penetrating wounds begin in man (5).

The realistic nature of the masses and velocities of glass fragments noted in Table 5 is established by the figures in Table 6 which details the masses and velocities for glass, stone and irregular steel objects empirically observed at stations located from the 1.9 to 17.3 psi lines during full-scale nuclear explosions at the Nevada Test Site. Unfortunately, to date, no fullscale missile experiments have been carried out to determine the expected missile environment inside a variety of industrial plants, office buildings 
Table 6

Relation Between Overpressure and Missile Parameters

\begin{tabular}{|c|c|c|c|c|c|c|}
\hline \multirow{2}{*}{$\begin{array}{c}\text { Max } \\
\text { pressure } \\
\text { psi } \\
\end{array}$} & \multirow{2}{*}{$\begin{array}{l}\text { Type of } \\
\text { missile }\end{array}$} & \multicolumn{2}{|c|}{ Velocity $\mathrm{ft} / \mathrm{sec}$} & \multicolumn{2}{|c|}{ Mass, gms } & \multirow{2}{*}{$\begin{array}{c}\text { Max missile } \\
\text { density } \\
\text { No/sq ft }\end{array}$} \\
\hline & & $\begin{array}{c}\text { geometric } \\
\text { mean }\end{array}$ & range & $\begin{array}{c}\text { geometric } \\
\text { mean }\end{array}$ & range & \\
\hline 1.9 & Window glass & 108 & $50-178$ & 1.45 & $0.03-10$ & 0.4 \\
\hline 3.8 & Window glass & $\cdot 168$ & $60-310$ & 0.58 & $0.01-10$ & 159 \\
\hline 5.0 & Window glass & 170 & $50-400$ & 0.13 & $0.002-140$ & 388 \\
\hline 8.5 & Natural stones & 275 & $167-413$ & 0.23 & $0.038-22.2$ & 35 \\
\hline 15.0 & Natural stones & 692 & $379-1100$ & 0.50 & $0.043-8.82$ & 4.7 \\
\hline 17.3 & Natural stones & 432 & $300-843$ & 0.21 & $0.010-13.4$ & 99.1 \\
\hline 17.3 & $\begin{array}{l}\text { Irregular steel } \\
\text { objects }\end{array}$ & 240 & $195-301$ & 34.5 & $9.0-86.0$ & 3.6 \\
\hline
\end{tabular}

A 
and other structures much larger than the "typical" brick and wooden frame houses to which past studies have been limited.

Objects striking the human head may cause skull fracture and concussion, both potentially dangerous experiences. Fortunately, quantitative investigations by Gurdjian, et al. (70), using human material, are available to support an estimate of the skull-fracture hazard. Using the data of these authors and adopting a missile of $10 \mathrm{lbs}$, which is near the average weight of the adult, human head, Table 7 was computed to state the impact velocities that can be associated with skull fracture. The table shows considerable variation in velocities required for fracture; e.g., the minimum impact velocity associated with fracture was near $15 \mathrm{ft} / \mathrm{sec}$, while the maximal without fracture was computed to be $2.3 .1 \mathrm{ft} / \mathrm{sec}$.

\section{Table 7}

Average Minimal Impact Velocities From a $10 \mathrm{lb}$. Missile Expected to Cause Skull Fracture and Maximal Velocity Without Fracture

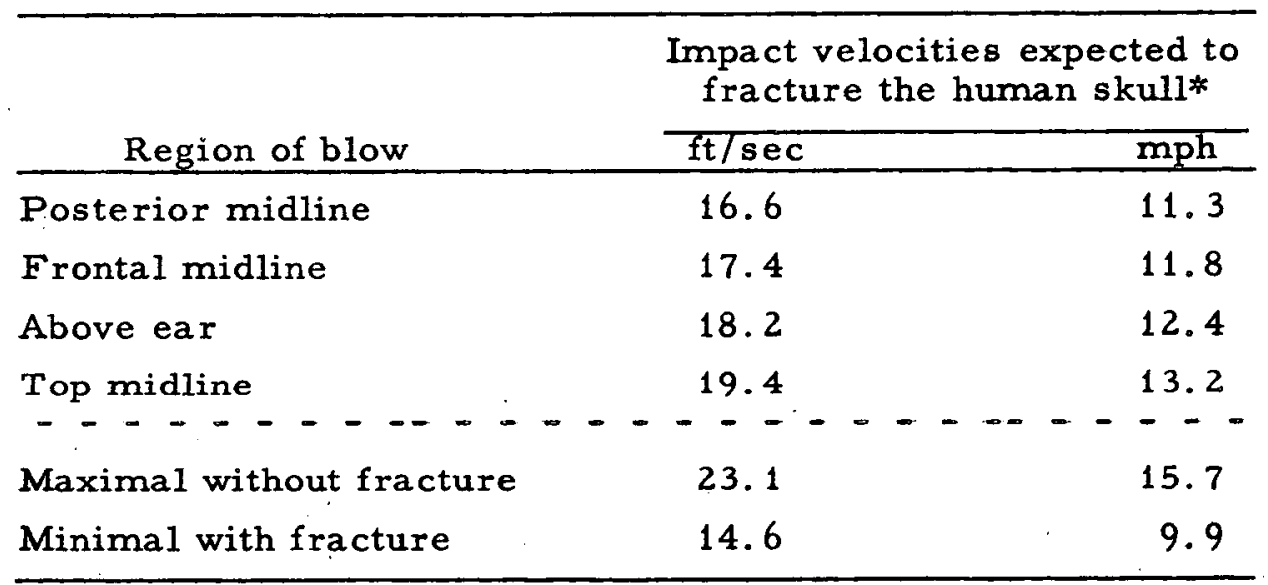

*Computed from the data of Gurdjian, et al. (70)

Although damage to the thorax and lungs from the impact of 0.4 and $0.8 \mathrm{lb}$. nonpenetrating missiles have been studied, information for heavier and lighter objects is lacking $(64,82)$. Also unavailable, are quantitative figures for missile impact velocities near and over the regions of the liver and spleen that will rupture these friable organs and produce hemorrhage often severe enough to require early surgery if fatality is to be avoided. 
Under such circumstances, $10 \mathrm{ft} / \mathrm{sec}$ has been adopted tentatively as the impact velocity for a $10 \mathrm{lb}$ nonpenetrating missile, below which the number of human injuries will approach a minimum.

\section{Tertiary Effects}

To deal simply with the hazards of displacement from blast-produced winds, it has been assumed that significant human injury will occur mostly during decelerative impact with solid objects having a mass much greater than that of man. Data from four sources has been selected as guides in. estimating threshold conditions for injury.

First, it is useful to note an animal study involving decelerative impact which reported the impact velocities associated with 50 per cent mortality in mice, rats, guinea pigs, and rabbits to be $38,44,31$ and $31 \mathrm{ft} / \mathrm{sec}$, respectively. Extrapolation of these figures to man predicts that on the average an impact velocity of $27 \mathrm{ft} / \mathrm{sec}$ or $18 \mathrm{mph}$ would be as sociated with death of half the individuals (82). These are interesting figures because National Safety Council reports on urban automobile accidents have associated a mortality of 40 per cent with automobile accidents at speeds of less than $20 \mathrm{mph}$ and a 70 per cent fatality rate with speeds of less than $30 \mathrm{mph}$ (69). Table 8 summarizes the above data.

Secondly, Black, et al. (76) dropped human cadavers feet first with knees locked onto a hard surface from heights of 1, 2, 3, 4 and 6 feet and concluded that the threshold for fracture of the heel, foot and ankle bones lay between impact velocities of 11 and $16 \mathrm{ft} / \mathrm{sec}$. Draeger, et al. (79) using an impact table and human cadavers to study ankle and foot fracture, demonstrated an impact velocity of $12-13 \mathrm{ft} / \mathrm{sec}(8-9 \mathrm{mph})$ to be near the threshold for skeletal fracture of the lower extremities.

Thirdly, Gurdjian, et al. (70), by drops onto a solid surface, subjected heads of human cadavers to impact loading and defined conditions for experimental skull fracture. The findings have been summarized in Table 9 in terms of impact velocity. Fracture was produced at a minimal impact velocity of $13.5 \mathrm{ft} / \mathrm{sec}(9.2 \mathrm{mph})$, while the maximal velocity without occurrence of fracture was $22.8 \mathrm{ft} / \mathrm{sec}(15.5 \mathrm{mph})$. These findings are fairly consistent with British work done during the Second World War $(76,78)$. 
Table 8

Average Velocities of Impact Against a Hard Surface Associated with 50 Per Cent Mortality of the Indicated Species of Animals with Extrapolation to Man*

\begin{tabular}{lcccc}
\hline $\begin{array}{l}\text { Species } \\
\text { of } \\
\text { Animal }\end{array}$ & $\begin{array}{c}\text { Average } \\
\text { animal } \\
\text { mass } \\
\text { gms }\end{array}$ & $\begin{array}{c}\text { Average impact velocity } \\
\text { for 50 per cent mortality }\end{array}$ & $\begin{array}{c}\text { Equivalent } \\
\text { height of fall } \\
\text { (approx.) } \\
\text { ft/sec }\end{array}$ & $\begin{array}{c}\text { mph } \\
\text { Mouse }\end{array}$ \\
\cline { 4 - 5 } & 19 & 38 & 26 & 22 \\
Rat & 180 & 44 & 30 & 30 \\
Guinea pig & 650 & 31 & 21 & 15 \\
Rabbit & 2,600 & 31 & 21 & 15 \\
\hline Man & 72,574 & 27 & 18 & 11 \\
(computed) & $(160 \mathrm{lbs})$ & & & \\
\hline
\end{tabular}

National Safety Council release on urban automobile accidents shows $\mathbf{4 0}$ and 70 per cent of fatalities were associated respectively with speeds of or less than 20 and $30 \mathrm{mph}$. - Quoted from De Haven.

* Data AEC Project, Lovelace Foundation, Albuquerque, N.M.

Table 9

The Ranges of Impact Velocities Associated with Experimental Fracture of the Human Skull

\begin{tabular}{|c|c|c|c|c|}
\hline $\begin{array}{c}\text { Range } \\
\text { impact } \\
\text { velocities } \\
\mathrm{ft} / \mathrm{sec} \\
\end{array}$ & $\begin{array}{l}\text { Approx: } \\
\text { velocity } \\
\text { in } \\
\text { mph } \\
\end{array}$ & $\begin{array}{l}\text { Approx. } \\
\text { height } \\
\text { of fall } \\
\text { in. } \\
\end{array}$ & $\begin{array}{l}\text { Number of } \\
\text { subjects }\end{array}$ & $\begin{array}{l}\text { Fractures } \\
\text { in } \\
\text { per cent }\end{array}$ \\
\hline $\begin{array}{r}13.5-14.9 \\
15-16.9 \\
17-18.9 \\
19-20.9 \\
21-22.9\end{array}$ & $\begin{array}{r}9.5 \\
10.9 \\
12.2 \\
\therefore 13.6 \\
15.0\end{array}$ & $\begin{array}{l}37 \\
48 \\
61 \\
75 \\
91\end{array}$ & $\begin{array}{r}9 \\
10 \\
12 \\
11 \\
4\end{array}$ & $\begin{array}{r}19 \\
22 \\
26 \\
24 \\
9\end{array}$ \\
\hline Total & : & $\because \quad \because$ & . . 46 & $\because 100$ \\
\hline
\end{tabular}

Minimum velocity with fracture - $13.5 \mathrm{ft} / \mathrm{sec}(9.2 \mathrm{mph})$

Maximum velocity with fracture $-22.8 \mathrm{ft} / \mathrm{sec}$ (15.5 mph)..

Maximum velocity without fracture - unstated. 
Fourthly, from the findings of Ruff (84), it is possible to deduce a velocity of about $8 \mathrm{ft} / \mathrm{sec}(6 \mathrm{mph})$ as likely to produce spinal fracture assuming impact with a solid surface in the sitting position.

The above data encourages one to adopt an impact velocity of $10 \mathrm{ft} / \mathrm{sec}$ as a tentative threshold criteria for human damage from abrupt decelerative impact following displacement by blast-produced winds. Though arbitrarily chosen, the $10 \mathrm{ft} / \mathrm{sec}(6.8 \mathrm{mph})$ figure is quite likely low enough to avoid any significant number of casualties and if serious injuries occur, they are likely to be few indeed.

Empirical work by Taborelli, et al. $(51,52)$ in the 1957 Nevada Test Series, using $160 \mathrm{lb}$ anthropometric dummies exposed at stations where measured overpressures were 5.3 and $6.9 \mathrm{psi}$, demonstrated the displacement possible to humans from nuclear blast. Table 10 summarizes the findings .

Table 10

Blast Displacement of $160 \mathrm{Lb}$ Anthropometric Dummies

\begin{tabular}{|c|c|c|c|c|c|}
\hline $\begin{array}{c}\text { Max } \\
\text { pressure } \\
\text { psi. }\end{array}$ & $\begin{array}{c}\operatorname{Max} \\
Q \\
\text { psi }\end{array}$ & $\begin{array}{l}\text { Initial } \\
\text { dummy } \\
\text { position }\end{array}$ & $\begin{array}{l}\text { Max } \\
\text { horizonta1 } \\
\text { velocity } \\
\mathrm{ft} / \mathrm{sec}\end{array}$ & $\begin{array}{c}\text { Time to } \\
\text { max } \\
\text { velocity } \\
\text { sec }\end{array}$ & $\begin{array}{l}\text { Displacement } \\
\text { in } \mathrm{ft}\end{array}$ \\
\hline \multirow[t]{2}{*}{5.3} & 1.8 & Standing & 21.4 & 0.5 & 21.9 downwind \\
\hline & & Prone & zero & - & None \\
\hline \multirow[t]{2}{*}{6.9} & 15.4 & Standing & not known & not known & $\begin{array}{l}256 \text { downwind } \\
44 \text { to right }\end{array}$ \\
\hline & & Prone & not known & not known & $\begin{array}{l}124 \text { downwind } \\
20 \text { to right }\end{array}$ \\
\hline
\end{tabular}

Even at 5 psi the maximal velocity attained in $0.5 \mathrm{sec}$ by the dummy was a little over $21.4 \mathrm{ft} / \mathrm{sec}$, which speed is well above those required to fractuie the skull and lower extremities. Though the displacement velocity at 6.9 psi was not obtained in the Nevada studies, the total displacement of 124 and $256 \mathrm{ft}$ for the prone and standing dummies, respectively, demonstrates the unequivocal displacement hazard which can occur following nuclear explosions. 


\section{Miscellaneous Effects}

No attempt has been made to deal with the threshold for human casua1ties as a consequence of miscellaneous blast effects. Those, however, who wish to explore the dangers from dust are referred to the publication of Desaga (80).

\section{Summary}

The tentative criteria described above for primary, secondary, and tertiary blast effects representing those conditions thought to be near the human casualty threshold are summarized in Table 11 . It is the current opinion of the writer that the data in Table 11 represent best estimates for conditions at which human casualties will approach a minimum; e.g., some individuals situated where the indicated overpressures, missile and displacement velocities exist will escape damage because of fortunate local geometry; many persons will be injured, but only to the extent that they can care for themselves; others will become casualties in that they require care from their associates, but these will be relatively few indeed.

\section{Table 11}

Threshold Criteria Estimated to be Near Conditions at Which Casualties Will Approach a Minimum or be Absent

\begin{tabular}{|c|c|}
\hline $\begin{array}{l}\text { Blast } \\
\text { Effect } \\
\end{array}$ & Criteria adopted as indicated \\
\hline Primary & 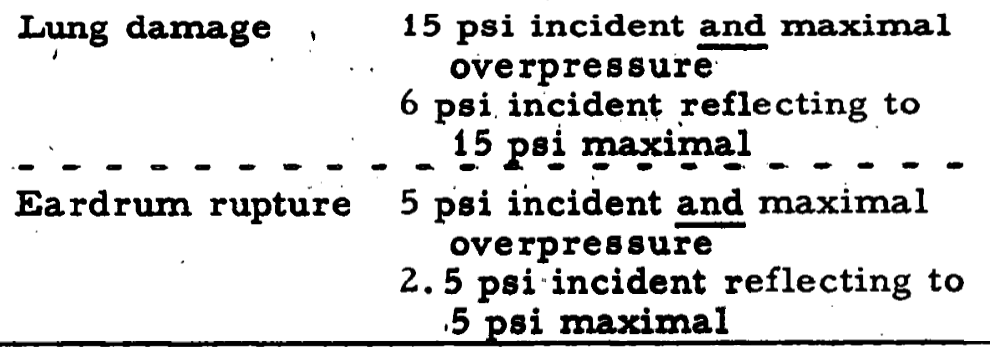 \\
\hline $\begin{array}{l}\text { Secondary } \\
\quad ; \quad ;\end{array}$ & 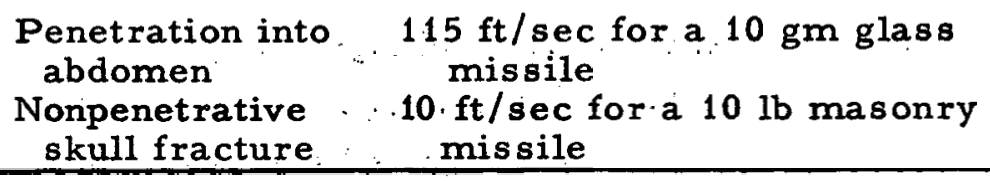 \\
\hline Tertiary & $\begin{array}{l}\text { Skull fracture } \\
\text { from impact }\end{array}$ \\
\hline
\end{tabular}


Relation of Blast Criteria to Nuclear Explosions*

An attempt will now be made to relate the arbitrarily chosen and tentative criteria for threshold biological blast damage to nuclear war. Specifically, the ranges and areas involved for potential damage to man will be presented only for surface nuclear detonations of 1 and $10 \mathrm{MT}$ explosive yields.

To aid inftial orientation, Figure 6 was prepared, using the data of Glasstone for surface bursts at sea level ( 85$)$. The figure shows iso-pressure lines from ${ }^{2} y^{5}$ to $100 \mathrm{psi}$ defining the expected range-yield relationships for detonations of megaton yield. The overpressures represent "free-field" phenomena - overpressures which would occur over open terrain in the absence of buildings and other structures - and are maximal incident pres sures measured side-on to the advancing pressure front.

\section{Primary Blast Effects}

Figure 6 contains iso-pressure lines for 2.5, 5, 6 and 15 psi which overpressures were noted in Table 11 to be related with the criteria adopted for primary blast effects. Table 12 notes these pressures and shows the ranges from ground zero and the areas covered for surface burst explosions of 1 and $10 \mathrm{MT}$.

With regard to the threshold of 5 psi maximal for beginning failure of the normal human eardrum, Table 12 shows that this effect can be expected out to ranges of 2.8 and $6.1 \mathrm{mi}$ for 1 and $10 \mathrm{MT}$ surface bursts, respectively, at which distance an incident and maximal "free-field" overpressure of 5 psi is predicted. The corresponding areas are 25 and 120 square miles.

* The author wishes to acknowledge the helpful cooperation of $\mathrm{Mr}$. I. G. Bowen, Head of the Physics Department, Lovelace Foundation, who contributed the analytical work required for formulating the tables and charts used in this section (86). 
Table 12

Ground Ranges and Areas for the Indicated Overpressures Arising from 1 and $10 \mathrm{MT}$ Surface Bursts at Sea Level

\begin{tabular}{|c|c|c|c|c|}
\hline \multirow{2}{*}{$\begin{array}{c}\text { Incident } \\
\text { Overpressure, } \\
\text { psi } \\
\end{array}$} & \multicolumn{4}{|c|}{$\begin{array}{c}\text { Corresponding Range and A rea } \\
1 \mathrm{MT}\end{array}$} \\
\hline & $\mathrm{mi}$ & $8 \mathrm{~g} \mathrm{mi}$ & $\overline{\mathrm{mi}}$ & $8 \mathrm{~g} \mathrm{mi}$ \\
\hline 2.5 & 4.5 & 64 & 9.7 & 300 \\
\hline 5.0 & 2.8 & 25 & 6.1 & 120 \\
\hline 6.0 & 2.6 & 21 & 5.5 & 95 \\
\hline 15.0 & 1.5 & 7.1 & 3.3 & 34 \\
\hline
\end{tabular}

In case exposure of man close to a reflecting surface or in other situations where reflections of pressure to 5 psi maximal might occur, it is necessary to note the distances and areas for $2.5 \mathrm{psi}$ incident overpressure, for the latter can and will reflect to 5 psi under appropriate conditions.

Thus, the maximal range for rupture of the tympanic membrane can be 4.5 and $9.7 \mathrm{mi}$, involving areas of 64 and $300 \mathrm{sq} \mathrm{mi}$ for the 1 and $10 \mathrm{MT}$ surface bursts, respectively.

Because rupture of the tympanic membrane can be regarded as a primary blast injury which is "acceptable" in an emergency, it is helpful to note the ranges and areas for the criteria adopted for lung damage. In a geometry of exposure conducive to producing sharp pressure reflection, Table 12 shows that human lung damage might occur out to 2.6 and $5.5 \mathrm{mi}$, covering areas of 21 and $95 \mathrm{sq} \mathrm{mi}$ for 1 and $10 \mathrm{MT}$ weapon yields, respectively, which data apply to the range of the "free-field" 6 psi incident overpressure assuming reflections to 15 psi maximal. For circumstances wherein pressure reflections would be minimal, the ranges for a free field incident overpiessure of $15 \mathrm{psi}$ would apply; e.g., ranges and areas of 1.5 $\mathrm{mi}$ and $7.1 \mathrm{sq} \mathrm{mi}$ for the $1 \mathrm{MT}$ and $3.3 \mathrm{mi}$ and $34 \mathrm{sq} \mathrm{mi}$ for the $10 \mathrm{MT}$ yields, respectively. 


\section{Secondary Effects}

The situation for biologic damage from impact with either penetrating or nonpentrating missiles is not quite so clear-cut as is the case with damage from overpressure. One complicating circumstance arises from the fact that blast energized missiles, depending upon their mass, size and shape and the magnitude of the blast winds, gain velocity as a function of time, and during the phase of increasing velocity cover a finite distance. This statement means, among other things, that the velocity at impact is a function of the distance (and time) the missile travels before striking a biologic target. Thus, any attempt to assess the missile hazard briefly, forces an arbitrary decision as to the distance a target might be from the potential source of missiles; e.g., if one were $10 \mathrm{ft}$ from a glass window, the missile velocity would be different than at 2,5 or $20 \mathrm{ft}$.

For the present analysis, $10 \mathrm{ft}$ of missile travel was a rbitrarily selected and used by Bowen in computing the figures presented in Table 13, setting forth the overpressures, ranges and areas for the missile criteria adopted previously (see Table 11). For example, the overpressures at which a $10 \mathrm{gm}$ glass missile would gain a velocity of $115 \mathrm{ft} / \mathrm{sec}$ in $10 \mathrm{ft}$ of travel were calculated to be $2.2 \mathrm{psi}$ for both the 1 and $10 \mathrm{MT}$ surface bursts. The overpressures are of similar value for the two yields because the missile gains velocity very rapidly in the early phases of its displacement. Differences between the 1 and $10 \mathrm{MT}$ yields only become apparent at distances of missile travel greater than $10 \mathrm{ft}$.

The $10 \mathrm{gm}-115 \mathrm{ft} / \mathrm{sec}-10 \mathrm{ft}$ criteria for the glass missile is met at ranges of 4.9 and $11 \mathrm{mi}$, covering 75 and $380 \mathrm{sq} \mathrm{mi}$ for 1 and $10 \mathrm{MT}$ surface bursts, respectively.

Likewise, Table 13 shows the overpressures, ranges and areas for the $10 \mathrm{lb}$ masonry missile to reach a velocity of $10 \mathrm{ft} / \mathrm{sec}$ in $10 \mathrm{ft}$ of travel. For 1 and $10 \mathrm{MT}$ yields the figures respectively are 2.4 and $2.1 \mathrm{psi}, 4.6$ and $11 \mathrm{mi}$, and 66 and $380 \mathrm{sq} \mathrm{mi}$.

In addition, Table 13 shows data applicable to circumstances for which the $10 \mathrm{lb}$ masonry missile was allowed to reach maximal velocity rather than 
Table 13

Overpressure and the Respective Ranges and Areas

Computed for the Indicated Missile Velocities Expected from a 1 and $10 \mathrm{MT}$ Surface

Burst at Sea Level

\begin{tabular}{|c|c|c|c|c|c|c|}
\hline & \multicolumn{6}{|c|}{$\frac{\text { Incident overpressures, ranges and areas }}{1 \mathrm{MT}}$} \\
\hline & psi & $\mathrm{mi}$ & $\mathrm{sq} \mathrm{mi}$ & psi & $\mathrm{mi}$ & sq mi \\
\hline $\begin{array}{l}10 \mathrm{gm} \text { glass fragment, } \\
115 \mathrm{ft} / \mathrm{sec} \text { in } 10 \mathrm{ft}:\end{array}$ & 2.2 & 4.9 & 75 & 2.2 & 11 & 380 \\
\hline $\begin{array}{l}10 \mathrm{lb} \text { masonry, } \\
10 \mathrm{ft} / \mathrm{sec} \text { in } 10 \mathrm{ft} \text { : }\end{array}$ & 2.4 & 4.6 & 66 & 2.1 & 11 & 380 \\
\hline $10 \mathrm{ft} / \mathrm{sec}:$ & $2.2 *$ & 4.9 & 75 & $1.5 *$ & 14 & 620 \\
\hline
\end{tabular}

*Minimum overpressure where a velocity of $10 \mathrm{ft} / \mathrm{sec}$ is predicted. Corresponding displacements are: $1 \mathrm{MT}-26 \mathrm{ft}$

$10 \mathrm{MT}-58 \mathrm{ft}$

the velocity over $10 \mathrm{ft}$ of travel. It is instructive to note that winds from a $1 \mathrm{MT}$ surface burst can energize a $10 \mathrm{lb}$ masonry missile to a maximum velocity of $10 \mathrm{ft} / \mathrm{sec}$ over $26 \mathrm{ft}$ of travel at a range of $4.9 \mathrm{mi}$ from ground zero where an overpressure of $2.2 \mathrm{psi}$ is expected. Area involved is computed to be $75 \mathrm{sq} \mathrm{mi}$. For the $10 \mathrm{MT}$ case, a velocity of $10 \mathrm{ft} / \mathrm{sec}$ over $58 \mathrm{ft}$ of missile travel can occur at a minimum overpressure of 1.5 pgi, reaching to $14 \mathrm{mi}$ and covering an area of $620 \mathrm{sq}$ miles.

\section{Tertiary Effects}

Dealing with the physical displacement of man involves treating man as a missile for computational purposes. As was the situation with the glass and masonry missiles, displacement velocity, among other things, is a function of time and distance. Calculations, for example, at 6 psi (Nevada altitude) for a yield of :10 MT indicate that a $160 \mathrm{lb}$ object would reach a maximal velocity of $97 \mathrm{ft} / \mathrm{sec}(66 \mathrm{mph})$, at which time the distance of travel would be $330 \mathrm{ft}$. Because there a re not yery many circumstances in which a man might be thrown hundrsds of feet without striking some object, data pre- 
pared for the present study were limited to displacement distances of 1,2 , 5 and $10 \mathrm{ft}$.

Consistent with this, Table 14 shows the overpressures, ranges and corresponding areas at which a $160 \mathrm{lb}$ human being would reach a velocity of $10 \mathrm{ft}$ per second in 1, 2, 5 and $10 \mathrm{ft}$ of travel. For $1 \mathrm{MT}$ yields, the corresponding overpressures range from 4.3 to 2.1 psi for displacement distances of 1 and $10 \mathrm{ft}$, respectively; the corresponding range and areas are 3.1 and $5.1 \mathrm{mi}$ and 30 and $82 \mathrm{sq} \mathrm{mi.} \mathrm{A} 10 \mathrm{MT}$ surface burst is similar overpressure-wise, being 4.3 and $1.8 \mathrm{psi}$ for a velocity of $10 \mathrm{ft} / \mathrm{sec}$ over 1 and $10 \mathrm{ft}$ displacements, respectively. However, the corresponding ranges and areas vary from 6.8 to $12 \mathrm{mi}$ and 150 and $450 \mathrm{sq} \mathrm{mi}$, respectively.

Minimum overpressures where a velocity of $10 \mathrm{ft} / \mathrm{sec}$ can be predicted for a $160 \mathrm{lb}$ man, involving displacements of 28 and $55 \mathrm{ft}$ at the time maximum velocity would be reached, are also given in Table 14. In these cases, ranges of 5.5 and $16 \mathrm{mi}$ and areas of 95 and $800 \mathrm{sq} \mathrm{mi}$ can be involved for the smaller and larger yields, respectively.

\section{Weapon-Threshold Criteria Summary}

A summary of the interrelations between the several tentative criteria adopted to estimate the thresholds of human injury from blast phenomena in terms of ranges and areas involved is given in Figure 7 for $1 \mathrm{MT}$ and in Figure 8 for the $10 \mathrm{MT}$ surface bursts. To a great extent, of course, the two figures reflect the arbitrary choice of criteria, but each serves to show the ranges from ground zero at which primary, secondary and tertiary blast casualties will begin. Stated another way, one can say that inside the ranges shown for each effect, blast-related casualties will progressively increase in number.

In general, Figures 7 and 8 indicate a trend implying that the potential hazard from displacement is more significant than missile damage and that missile damage, in turn, is more important than primary blast injury. To be sure, conditions at the time of exposure will be critical, and no doubt entirely unpredictable for ar uninformed and unprotected population under nuclear attack. 
Table 14

Overpressures Computed for an Expected Displacement $V$ elocity of $10 \mathrm{ft} / \mathrm{sec}$ for a $160 \mathrm{lb}$. Human Being Travelling the Indicated Distances. Ranges and Areas Computed for Surface Bursts at Sea Level

\begin{tabular}{|c|c|c|c|c|c|c|}
\hline \multirow{2}{*}{$\begin{array}{c}\text { Displacement in } \\
\mathrm{ft} \text { corresponding } \\
\text { to velocity of } \\
10 \mathrm{ft} / \mathrm{sec}\end{array}$} & \multicolumn{6}{|c|}{$\frac{\text { Incident pressure and corresponding range and a rea }}{1 \mathrm{MT}}$} \\
\hline & $\overline{\mathrm{psi}}$ & $\mathrm{mi}$ & $\mathrm{sq} \mathrm{mi}$ & $\overline{\mathrm{psi}}$ & $\mathrm{mi}$ & $\mathrm{sq} \mathrm{mi}$ \\
\hline 1 & 4.3 & 3.1 & 30 & 4.3 & 6.8 & 150 \\
\hline 2 & 3.3 & 3.7 & 43 & 3.3 & 8.0 & 200 \\
\hline 5 & 2.4 & 4.7 & 69 & 2.3 & 10 & 310 \\
\hline \multirow{2}{*}{10} & 2.1 & 5.1 & 82 & 1.8 & 12 & 450 \\
\hline & $1.9 *$ & 5.5 & 95 & 1. 3* & 16 & 800 \\
\hline
\end{tabular}

* Minimum overpressure where velocity of $10 \mathrm{ft} / \mathrm{sec}$ is predicted. Corresponding displacements are: $1 \mathrm{MT}-28 \mathrm{ft}$

$10 \mathrm{MT}-58 \mathrm{ft}$ (After Bowen (86))

With regard to this statement, it is clear that if one were to stand against a wall to avoid exposure to blast winds, displacement injury might not occur, but the hazard from pressure reflections would be increased. Likewise, avoiding contact with firm surfaces to minimize injury from overpressure markedly increases the dangers of displacement. In either case, there exists the missile hazard, and the data clearly indicate that much in the way of protection could be achieved by avoiding blast winds and missiles whether the latter are those impelled by the blast winds or fall due to gravity following the passage of the pressure pulse. In quantitative terms, protection from missiles and blast winds - which might be achieved using a simply constructed fallout shelter - might well reduce the range of serious blast hazards from a $10 \mathrm{MT}$ surface burst from $16 \mathrm{mi}$ (Table 14) to $3.3 \mathrm{mi}$ (Table 12), a difference in a rea involving 800 minus 34 or 766. sq mi.

There can be no question of the worth of such measures to avoid blast 
casualties, but an understanding of the feasibility of protection from nuclear weapons involves consideration of factors other than blast effects.

\section{Relation of Blast to Other Effects}

To gain some perspective with regard to the total problem of protection, Table 15 was prepared using data from Glasstone (85) and is presented in preliminary form to point out the need for assessing the relative importance of thermal and initial ionizing radiation compared with blast phenomena. Though the figures for thermal radiation shown are well above those ordinarily assigned for first and second degree burns of the skin at all overpressures associated with the blast criteria presented in Tables 12, 13 and $14-$ as is summarized in Tables 16 and 17 - it is nevertheless true that the missile hazard is worse inside buildings than in the open. Germane to this remark, is the fact that thermal fluxes noted in Tables 15, 16 and 17 are those for "free-field" conditions and they will actually be much lower by some unknown amount inside structures; e.g., conditions which maximize the missile hazard, tend to minimize injuries from thermal radiation.

Also, the figures for prompt ionizing radiation are of importance. Interestingly enough, even up to overpressures of 15 psi used as one of the primary blast criteria, prompt radiation expected for the $10 \mathrm{MT}$ case is only about 10 rem (see Tables 15 and 17 ). Since this is an easily acceptable radiation flux in an emergency, one can say that prompt radiation represents no hazard beyond the $15 \mathrm{psi}$ range $(3.3 \mathrm{mi}-34 \mathrm{sq} \mathrm{mi})$.

For 1 MT surface bursts, however, prompt radiation at the $15 \mathrm{psi}$ range ( $1.5 \mathrm{mi}-7.1 \mathrm{sq} \mathrm{mi}$ ) is $500 \mathrm{rem}$, a dose to be avoided at all costs (see Tables 15 and 16). Thinking in this vein leads one to remark that protection against missiles and blast winds should be easy - a simple fallout shelter, for example. The use of such protection, however, will serve to degrade both thermal radiation and the "free-field" prompt radiation "doses" by whatever factor is appropriate to the shielding characteristics of the shelter. In any case, effective protection at overpressures of $15 \mathrm{psi}$ is not difficult and only simple technical problems are involved in its achievement. 
Table 15.

Various Effects of Biological Interest as a Function of Range from Ground Zero for 1 and $10 \mathrm{MT}$ Surface Burst at Sea Level

\begin{tabular}{|c|c|c|c|c|c|c|c|c|}
\hline \multirow{2}{*}{$\begin{array}{c}\text { Range } \\
\mathrm{mi}\end{array}$} & \multicolumn{4}{|c|}{$1 \mathrm{MT}$} & \multicolumn{4}{|c|}{$10 \mathrm{MT}$} \\
\hline & $\mathrm{P}$ & IR & TR & V & $\bar{P}$ & IR & TR & V \\
\hline .6 & $>100$ & $>3000$ & 880 & & $>100$ & $>3000$ & $>1000$ & \\
\hline .8 & 62 & $>3000$ & 470 & & $>100$ & $>3000$ & $>1000$ & \\
\hline 1.0 & 37 & $>3000$ & 290 & & $>100$ & $>3000$ & $>1000$ & \\
\hline 1.2 & 2.5 & $>3000$ & 200 & 150 & $>100$ & $>3000$ & $>1000$ & \\
\hline 1.5 & 16 & 500 & 120 & 100 & 88 & $>3000$ & $>1000$ & \\
\hline 2.0 & 9.2 & 40 & 65 & 60 & 44 & 850 & 650 & \\
\hline .2 .5 & 6.2 & $<10$ & 40 & 39 & 27 & 120 & 400 & \\
\hline 3.0 & 4.6 & $<10$ & 27 & 28 & 18 & 23 & 270 & 110 \\
\hline 4.0 & 3.0 & $<10$ & 14 & 17 & 10 & $<10$ & 140 & 65 \\
\hline 5.0 & 2.2 & $<10$ & 8.8 & 11 & 7.1 & $<10$ & 88 & 46 \\
\hline 6.0 & 1.7 & $<10$ & 6.0 & 7.6 & 5.2 & $<10$ & 60 & 32 \\
\hline 8 & 1.1 & $<10$ & 3.2 & 3.9 & 3.3 & $<10$ & 32 & 20 \\
\hline 10 & $<1$ & $<10$ & 2.0 & & 2.4 & $<10$ & 20 & 14 \\
\hline 12 & $<1$ & $<10$ & 1.3 & & 1.9 & $<10$ & 13 & 11 \\
\hline 15 & $<1$ & $<10$ & .81 & & 1.4 & $<10$ & 8.1 & 7.5 \\
\hline 20 & $<1$ & $<10$ & .44 & & $<1$ & $<10$ & 4.4 & \\
\hline 25 & $<1$ & $<10$ & .27 & & $<1$ & $<10$ & 2.7 & \\
\hline 30 & $<1$ & $<10$ & .18 & & $<1$ & $<10$ & 1.8 & \\
\hline 35 & $<1$ & $<10$ & .13 & & $<1$ & $<10$ & 1.3 & \\
\hline 40 & $<1$ & $<10$ & $<.1$ & & $<1$ & $<10$ & $<1$ & \\
\hline
\end{tabular}

$P=$ peak overpressure in psi

$I R$ = ionizing radiation, exposure dose in rem (initial)

$T R=$ the rmal radiation in $\mathrm{cal} / \mathrm{cm}^{2}$

$V=$ velocity predicted for $160 \mathrm{lb}$ man in a translation distance of $10 \mathrm{ft}$

Pressure and radiation data from Effects of Nuclear Weapons 
This leaves onelast major early effect of weapons - the residual radiation - to assess in relation to blast effects. This problem, along with firestorm, has been considered beyond the scope of this presentation, but a few general remarks a re nonetheless indicated.

First, the greatest population density is likely to be within the range of those weapon-produced hazards developing in a matter of seconds and minutes after an explosion - blast, prompt ionizing and thermal radiation effects. Because of the large number of people involved, these "early" effects and the need for protection from them cannot be ignored. Further, the nature and unpredictability of the residual radiation, particularly that due to fallout and the high levels involved from the latter, makes evacuation an unattractive policy. Under such circumstances the levels of residual radiation to be expected at very close ranges from ground zero-like $1,2,5$, $10,15,20$ and 30 miles - should and must be estimated if planning for maximal protection is to be sensible and complete. There can be no doubt that this is a critical problem and one regarding which very little empirical data are available.

Even without introducing thinking regarding protection, the "very close in" residual radiation levels need to be known to aid understanding and estimating the "cost" of nuclear war to a nation whose population is practically "naked" and completely unprepared and unprotected for a full-scale nuclear attack. 
Table 16

Comparative Weapons Effect Data Applicable to Indicated Blast Criteria for a $1 \mathrm{MT}$ Surface Burst at Sea Level

\begin{tabular}{|c|c|c|c|c|}
\hline $\begin{array}{l}\text { Incident } \\
\text { over- } \\
\text { pressure } \\
\text { psi }\end{array}$ & $\begin{array}{l}\text { Range } \\
\text { in } \\
\mathrm{mi}\end{array}$ & $\begin{array}{l}\text { Initial } \\
\text { ionizing } \\
\text { radiation } \\
\text { rem }\end{array}$ & $\begin{array}{l}\text { Thermal } \\
\text { radiation } \\
\text { cal/cm }\end{array}$ & $\begin{array}{l}\text { Blast criteria for primary, } \\
\text { secondary and tertiary } \\
\text { effects }\end{array}$ \\
\hline 1.9 & 5.5 & $<10$ & 7.2 & $\begin{array}{l}\text { Displacement of man } 160 \mathrm{lb} \\
10 \mathrm{ft} / \mathrm{sec} \text { in } 28 \mathrm{ft}\end{array}$ \\
\hline 2.1 & 5.1 & $<10$ & 8.4 & $\begin{array}{l}\text { Displacement of man } 160 \mathrm{lb} \\
10 \mathrm{ft} / \mathrm{sec} \text { in } 10 \mathrm{ft}\end{array}$ \\
\hline 2.2 & 4.9 & $<10$ & 9.3 & $\begin{array}{r}\text { Missiles (glass) } 10 \mathrm{gm} \\
115 \mathrm{ft} / \mathrm{sec} \text { in } 10 \mathrm{ft}\end{array}$ \\
\hline 2.2 & 4.9 & $<10$ & 9.3 & $\begin{array}{c}\text { Missiles (masonry) } 10 \mathrm{lbs} \\
10 \mathrm{ft} / \mathrm{sec} \text { in } 26 \mathrm{ft}\end{array}$ \\
\hline 2.4 & 4.6 & $<10$ & 10 & $\begin{array}{c}\text { Missiles (masonry) } 10 \mathrm{lbs} \\
10 \mathrm{ft} / \mathrm{sec} \text { in } 10 \mathrm{ft}\end{array}$ \\
\hline 2.5 & 4.5 & $<10$ & 11 & $\begin{array}{l}\text { Eardrum rupture assuming } \\
\text { pressure reflection }\end{array}$ \\
\hline 4.3 & 3.1 & $<10$ & 25 & $\begin{array}{l}\text { Displacement of man } 160 \mathrm{lb} \\
10 \mathrm{ft} / \mathrm{sec} \text { in } 1 \mathrm{ft}\end{array}$ \\
\hline 5.0 & 2.8 & $<10$ & 31 & $\begin{array}{c}\text { Eardrum rupture, as suming } \\
\text { no pressure reflection }\end{array}$ \\
\hline 6.0 & 2.6 & $<10$ & 37 & $\begin{array}{c}\text { Lung damage assuming } \\
\text { pressure reflection }\end{array}$ \\
\hline 15.0 & 1.5 & 500 & 120 & $\begin{array}{l}\text { Lung damage as suming } \\
\text { no pressure reflection }\end{array}$ \\
\hline
\end{tabular}

Computed and prepared by Bowen(86) 
Table 17

Comparative Weapons Effect Data

Applicable to Indicated Blast Criteria

for a $10 \mathrm{MT}$ Surface Burst at Sea Level

\begin{tabular}{|c|c|c|c|c|}
\hline $\begin{array}{l}\text { Incident } \\
\text { over- } \\
\text { pressure } \\
\text { psi }\end{array}$ & $\begin{array}{c}\text { Range } \\
\text { in } \\
\mathrm{mi}\end{array}$ & $\begin{array}{l}\text { Initial } \\
\text { ionizing } \\
\text { radiation } \\
\text { rem }\end{array}$ & $\begin{array}{l}\text { Thermal } \\
\text { radiation } \\
\mathrm{cal} / \mathrm{cm}^{2}\end{array}$ & $\begin{array}{l}\text { Blast criteria for primary, } \\
\text { secondary and tertiary } \\
\text { effects }\end{array}$ \\
\hline 1.3 & 16 & $<10$ & 7.2 & $\begin{array}{l}\text { Displacement of man } 160 \mathrm{lb} \\
10 \mathrm{ft} / \mathrm{sec} \text { in } 58 \mathrm{ft}\end{array}$ \\
\hline 1.5 & 14 & $<10$ & 9.5 & $\begin{array}{c}\text { Missiles (masonry) } 10 \mathrm{lb} \\
10 \mathrm{ft} / \mathrm{sec} \text { in } 58 \mathrm{ft}\end{array}$ \\
\hline 1.8 & 12 & $<10$ & 13 & $\begin{array}{c}\text { Displacement of man } 160 \mathrm{lb} \\
10 \mathrm{ft} / \mathrm{sec} \text { in } 10 \mathrm{ft}\end{array}$ \\
\hline 2.1 & 11 & $<10$ & 16 & $\begin{array}{c}\text { Missiles (ma sonry) } 10 \mathrm{lb} \\
10 \mathrm{ft} / \mathrm{sec} \text { in } 10 \mathrm{ft}\end{array}$ \\
\hline 2.2 & 11 & $<10$ & 16 & $\begin{array}{l}\text { Missiles (glass) } 10 \mathrm{gm} \\
115 \mathrm{ft} / \mathrm{sec} \text { in } 10 \mathrm{ft}\end{array}$ \\
\hline 2.5 & 9.7 & $<10$ & 21 & $\begin{array}{c}\text { Eardrum rupture assuming } \\
\text { pressure reflection }\end{array}$ \\
\hline 4.3 & 6.8 & $<10$ & 46 & $\begin{array}{l}\text { Displacement of man } 160 \mathrm{lb} \\
10 \mathrm{ft} / \mathrm{sec} \text { in } 1 \mathrm{ft}\end{array}$ \\
\hline 5.0 & 6.1 & $<10$ & 58 & $\begin{array}{c}\text { Eardrum rupture assuming } \\
\text { no pressure reflection }\end{array}$ \\
\hline 6.0 & 5.5 & $<10$ & 74 & $\begin{array}{l}\text { Lung damage assuming } \\
\text { pressure reflection }\end{array}$ \\
\hline 15.0 & 3.3 & 10 & 220 & $\begin{array}{l}\text { Lung damage as suming } \\
\text { no pressure reflection }\end{array}$ \\
\hline
\end{tabular}




\section{$\underline{\text { Summa ry }}$}

1. The scope and nature of biological blast effects were noted and briefly described.

2. Four categories of blast hazards were defined as follows:

a. primary effects due to blast-produced overpressures and their reflections,

b. secondary effects from damage following the impact of penetrating and nonpenetrating missiles energized by blast pressures and winds and gravity,

c. tertiary effects involving injuries occurring as a consequence of displacement of a biological target by blast shock and winds, and

d. miscellaneous injuries tue to ground shock, dust and blast associated thermal phenomena.

3. The character of primary, secondary and tertiary blast hazards was described to emphasize the seriousness of blast-produced injuries.

4. In further emphasis of the danger, the occurrence of combined injuries from pressure, missiles and displacement was discussed and actual experiences in the Texas City Disaster of 1947 involving over 550 dead or missing, 800 hospitalizations, and between 3000 and 4000 additional casualties were cited to make clear the need for immediate and prolonged care to avoid fatalities if blast injuries a re allowed to occur.

5. Selected data relating environmental conditions defining gross biologic damage from overpressures, missiles and impact loading were presented as background for fixing tentative, but conservative threshold criteria for human casualties from blast.

6. A casualty was defined simply as an individual sufficiently injured to be unable to care for himself and thus become a burden to someone else.

7. The tentative criteria adopted were as follows:

a. Primary blast effects based on (1) lung damage at an 
incident and maximal pressure of $15 \mathrm{psi}$ and at 6 psi incident overpressure for conditions wherein a reflection to 15 psi max occurs, and (2) rupture of the eardrum beginning at an incident and maximal overpressure of 5 psi and at an incident overpressure of 2.5 psi under circumstances whe re reflection to 5 psi max will occur.

b. Secondary blast effects for penetrating and nonpenetrating missiles; the former referred to a $10 \mathrm{gm}$ glass missile having a velocity of $115 \mathrm{ft} / \mathrm{sec}$ which has a 1 per cent probability of traversing the abdominal wall of a dog and entering the abdominal cavity; the latter was estimated - considering a $10 \mathrm{lb}$ masonry missile travelling $10 \mathrm{ft} / \mathrm{sec}$ as having only a slight chance of producing significant head and body injury.

c. Tertiary blast effects assumed damage only on decelerative impact, and displacements involving velocities of $10 \mathrm{ft} / \mathrm{sec}$ for a $160 \mathrm{lb}$ man were considered low enough to avoid significant numbers of serious head and skeletal injuries.

8. The tentative criteria arbitra rily adopted to "fix" the threshold for blast casualties were related to nuclear weapons of 1 and $10 \mathrm{MT}$ yield, surface detonated at sea level, in terms of overpressures, ranges and areas involved.

9. The maximal ranges at which primary effects would be noted were estimated as follows:

$\begin{array}{lll}\text { Effect } & 1 \mathrm{MT} & 10 \mathrm{MT} \\ { } } & 4.5 \mathrm{mi} & 9.7 \mathrm{mi} \\ \text { Lung damage } & 2.6 \mathrm{mi} & 5.5 \mathrm{mi}\end{array}$

10. The estimated maximal areas involved for primary effects were:

Effect

Eardrum rupture

Lung damage
$1 \mathrm{MT} \quad 10 \mathrm{MT}$

$64 \mathrm{sq} \mathrm{mi} 300 \mathrm{sq} \mathrm{mi}$

$21 \mathrm{sq} \mathrm{mi} 95 \mathrm{sq} \mathrm{mi}$ 
11. The distance travelled by a blast energized missile before impact was noted as one critical factor in determining impact velocity.

12. The estimated ranges at which casualties from penetrating and nonpenetrating missiles would begin for the 1 and $10 \mathrm{MT}$ surface bursts at sea level were:

\begin{tabular}{lllll}
$\begin{array}{c}\text { Type } \\
\text { Missile }\end{array}$ & $\begin{array}{l}\text { Weight } \\
\text { Missile }\end{array}$ & $\begin{array}{l}\text { Distance } \\
\text { to impact }\end{array}$ & \multicolumn{2}{c}{ Range } \\
\hline Glass & $10 \mathrm{gm}$ & $10 \mathrm{ft}$ & $4.9 \mathrm{mi}$ & $11 \mathrm{mi}$ \\
Masonry & $10 \mathrm{lb}$ & $10 \mathrm{ft}$ & $4.6 \mathrm{mi}$ & $11 \mathrm{mi}$ \\
Masonry & $10 \mathrm{lb}$ & $26 \mathrm{ft}$ & $4.9 \mathrm{mi}$ & \\
Masonry & $10 \mathrm{lb}$ & $58 \mathrm{ft}$ & & $14 \mathrm{mi}$
\end{tabular}

13. The corresponding estimated areas over which missile casualties could be expected were:

\begin{tabular}{llccc}
$\begin{array}{c}\text { Type } \\
\text { Missile }\end{array}$ & $\begin{array}{c}\text { Weight } \\
\text { Missile }\end{array}$ & $\begin{array}{c}\text { Distance } \\
\text { to impact }\end{array}$ & 1 MT & $10 \mathrm{MT}$ \\
\hline Glass & $10 \mathrm{gm}$ & $10 \mathrm{ft}$ & $75 \mathrm{sq} \mathrm{mi}$ & $380 \mathrm{sq} \mathrm{mi}$ \\
Masonry & $10 \mathrm{lb}$ & $10 \mathrm{ft}$ & $66 \mathrm{sq} \mathrm{mi}$ & $380 \mathrm{sq} \mathrm{mi}$ \\
Masonry & $10 \mathrm{lb}$ & $26 \mathrm{ft}$ & $75 \mathrm{sq} \mathrm{mi}$ & \\
Masonry & $10 \mathrm{lb}$ & $58 \mathrm{ft}$ & & $620 \mathrm{sq} \mathrm{mi}$
\end{tabular}

14. Casualties due to displacement, among other things, were noted to involve the distance of travel before impact.

15. Thus, the estimated ranges over which casualties could be expected for the $160 \mathrm{ib}$ human travelling $10 \mathrm{ft} / \mathrm{sec}$ varied with displacement distance at impact for the surface bursts at sea level as follows:

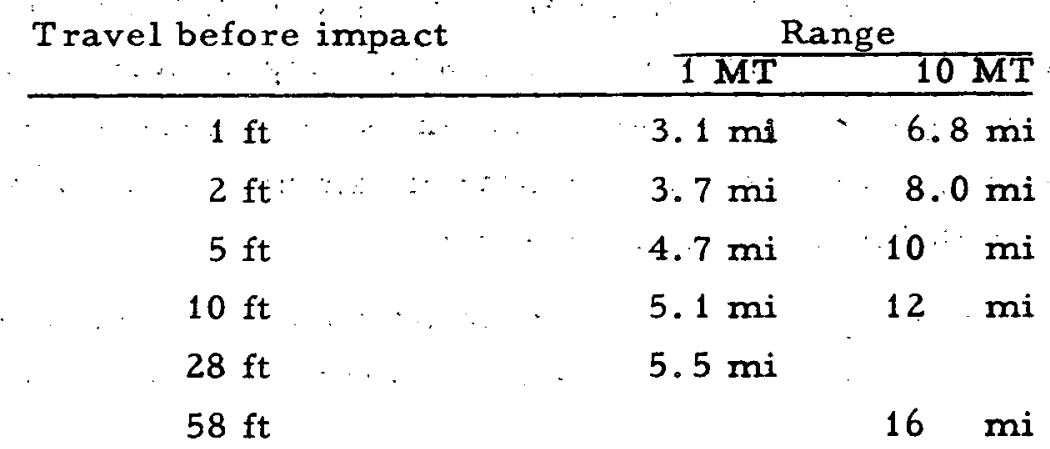


16. The corresponding areas involved for displacement-related human casualties were estimated as:

\begin{tabular}{ccc} 
Travel before impact & $1 \mathrm{MT}$ & $10 \mathrm{MT}$ \\
\hline $1 \mathrm{ft}$ & $30 \mathrm{sq} \mathrm{mi}$ & $150 \mathrm{sq} \mathrm{mi}$ \\
$2 \mathrm{ft}$ & $43 \mathrm{sq} \mathrm{mi}$ & $200 \mathrm{sq} \mathrm{mi}$ \\
$5 \mathrm{ft}$ & $69 \mathrm{sq} \mathrm{mi}$ & $310 \mathrm{sq} \mathrm{mi}$ \\
$10 \mathrm{ft}$ & $82 \mathrm{sq} \mathrm{mi}$ & $450 \mathrm{sq} \mathrm{mi}$ \\
$28 \mathrm{ft}$ & $95 \mathrm{sq} \mathrm{mi}$ & \\
$58 \mathrm{ft}$ & & $800 \mathrm{sq} \mathrm{mi}$
\end{tabular}

17. For megaton yields the estimated displacement hazard from blast reached to greater ranges from ground zero than those estimated for missile damage and the latter to greater distances than those expected for pressure injury.

18. Judging by the estimated areas involved, about 5 per cent of the blast hazard from a $10 \mathrm{MT}$ surface burst arises from casualties related directly to overpressure while near 95 per cent concern damage from missiles and displacement.

19. The relation of nuclear blast effects to the rmal and initial ionizing radiation were tabulated in preliminary form.

20. The absence of any hazard from initial ionizing radiation from a $10 \mathrm{MT}$ surface burst over the entire range noted for blast casualties in to a distance of $3.3 \mathrm{mi}\left(15 \mathrm{psi}, 10 \mathrm{rem}\right.$ initial ionizing radiation, $220 \mathrm{cal} / \mathrm{cm}^{2}$ ) was pointed out.

21. The tabular data presented for "free-field" effects of megaton surface bursts emphasized the short ranges for danger from initial ionizing radiation compared with the ranges for the several blast hazards; likewise, the relatively greater distances compared with blast effects, for potential damage from thermal radiation were noted.

22. The logic of seeking appropriate cover to avoid human casualties from thermal, displacement, missile and pressure effects was discussed 
and the associated gain in shielding from residual and initial radiation was mentioned.

23. The need for estimating residual radiation levels expected at very close ranges from ground zero was thought critical, for any assessment of the total "cost" of nuclear war to a nation requires appreciation of the total hazards, including those to the entire population, from all untoward effects which occur as a consequence of nuclear explosions. 


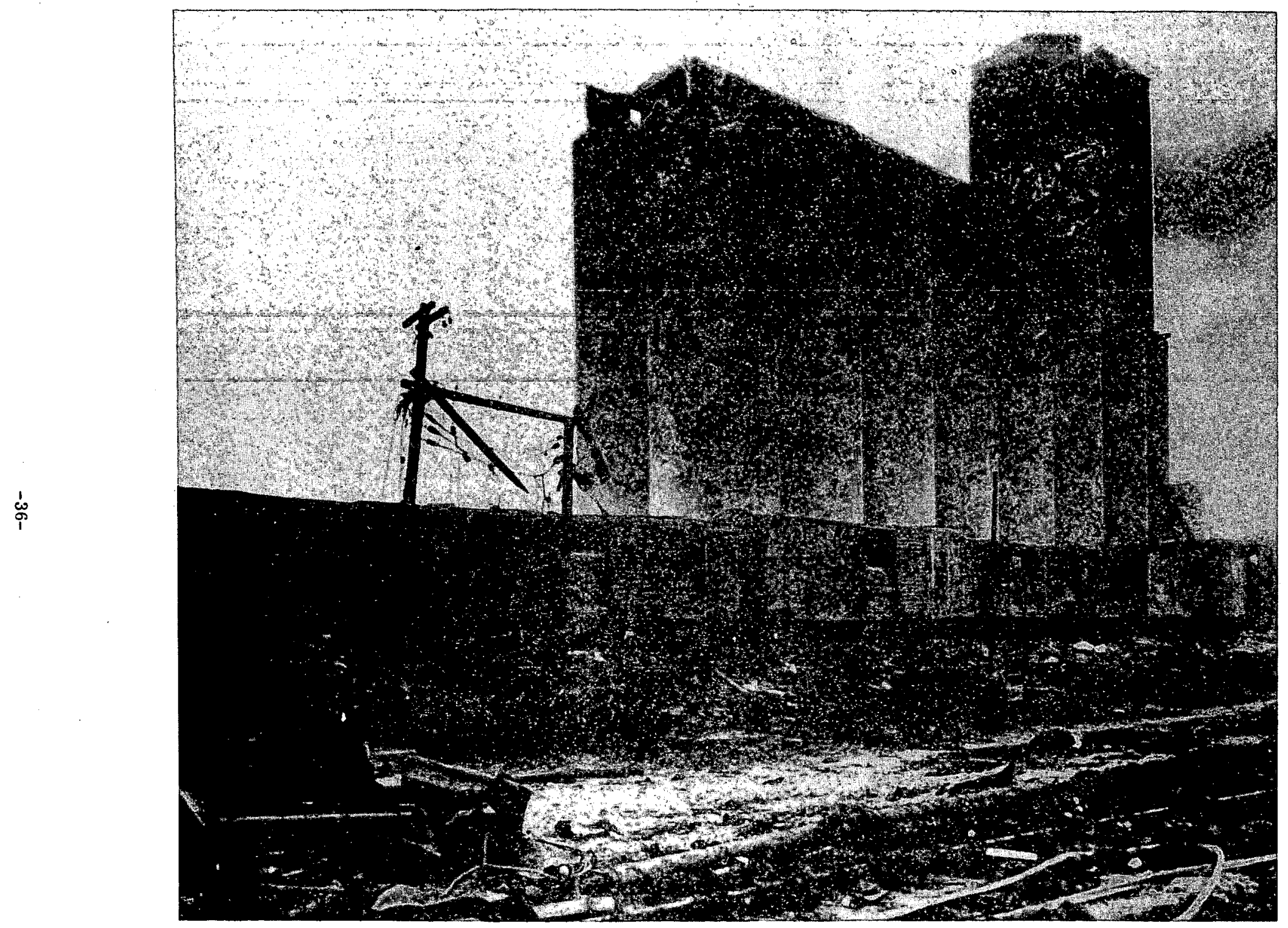

Figure 1. Missile and other blast damage to a grain elevator located approximately 600-900 ft from the explosions at Texas City. After Armistead (81). 


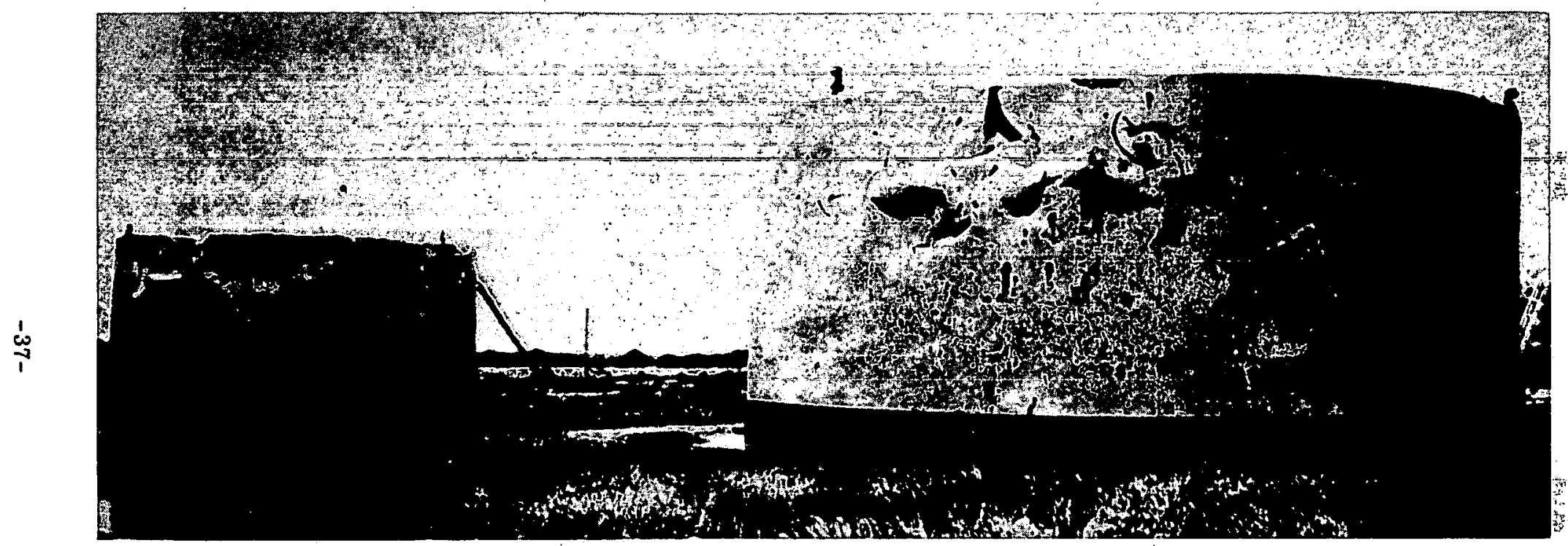

Figure 2. Missile and other blast damage to liquid storage tanks located about $3200 \mathrm{ft}$ from one of the Texas City explosions. After Armistead (81). 


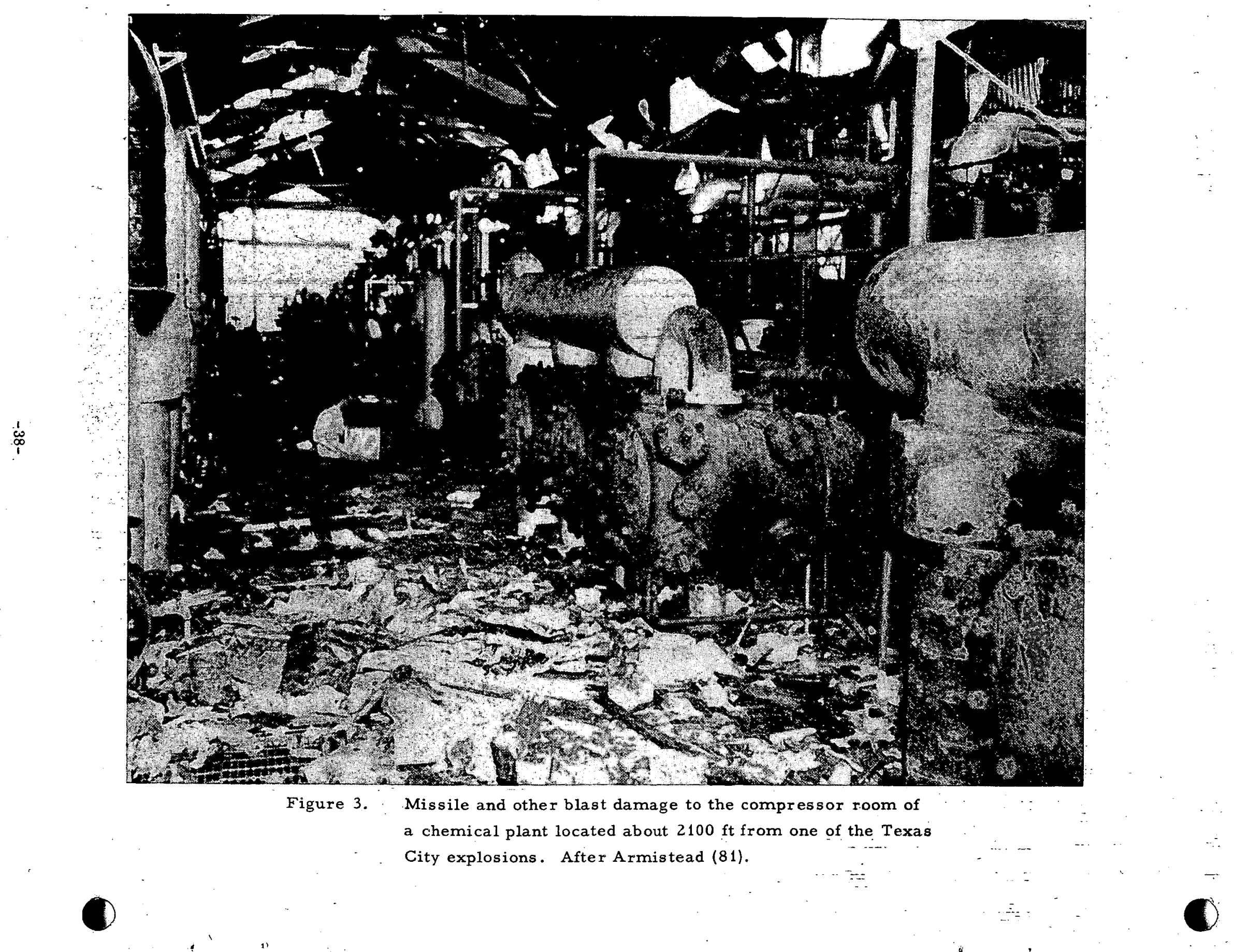




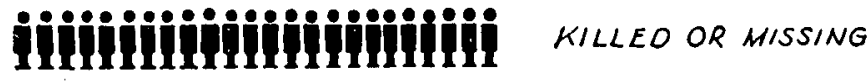

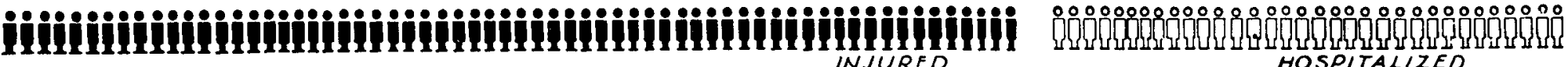

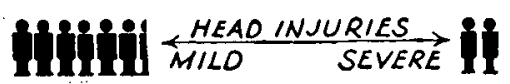

iihiiiiiiiiiil MAJOR LACERATONS

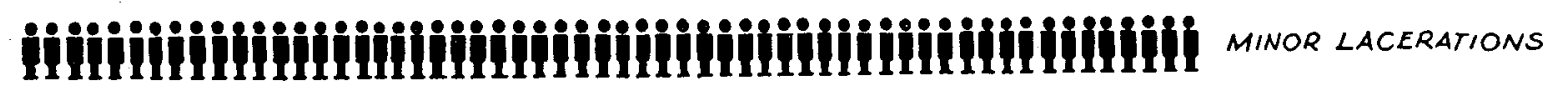

iiiiiiii เuNo

III ABOOMEN
$i$ KIONEY ANO BLADOER

iiilil $\frac{\text { EARORUM }}{\text { OOTH }}$ iiliij

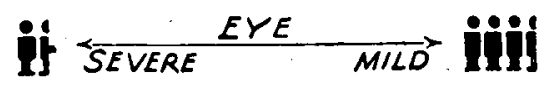

j SEVERE $_{\text {BURNS }}^{\text {MILO }}$ ii

if amputations

$=25$ CASUALTIES

CLASSIFICATION OF FRACTURES

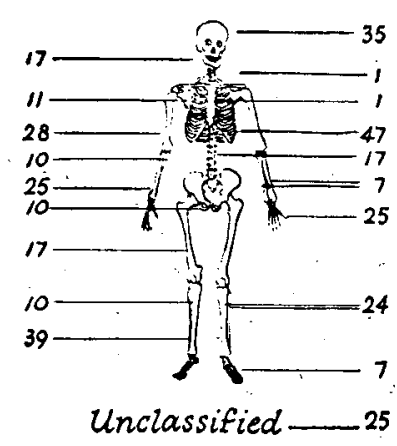

\section{iiiliiiiiiiiili FRACTURES}

Figure 5. Comparison of the types of damages suffered by the injured at the Texas City Disaster. After Blocker and Blocker (39). 

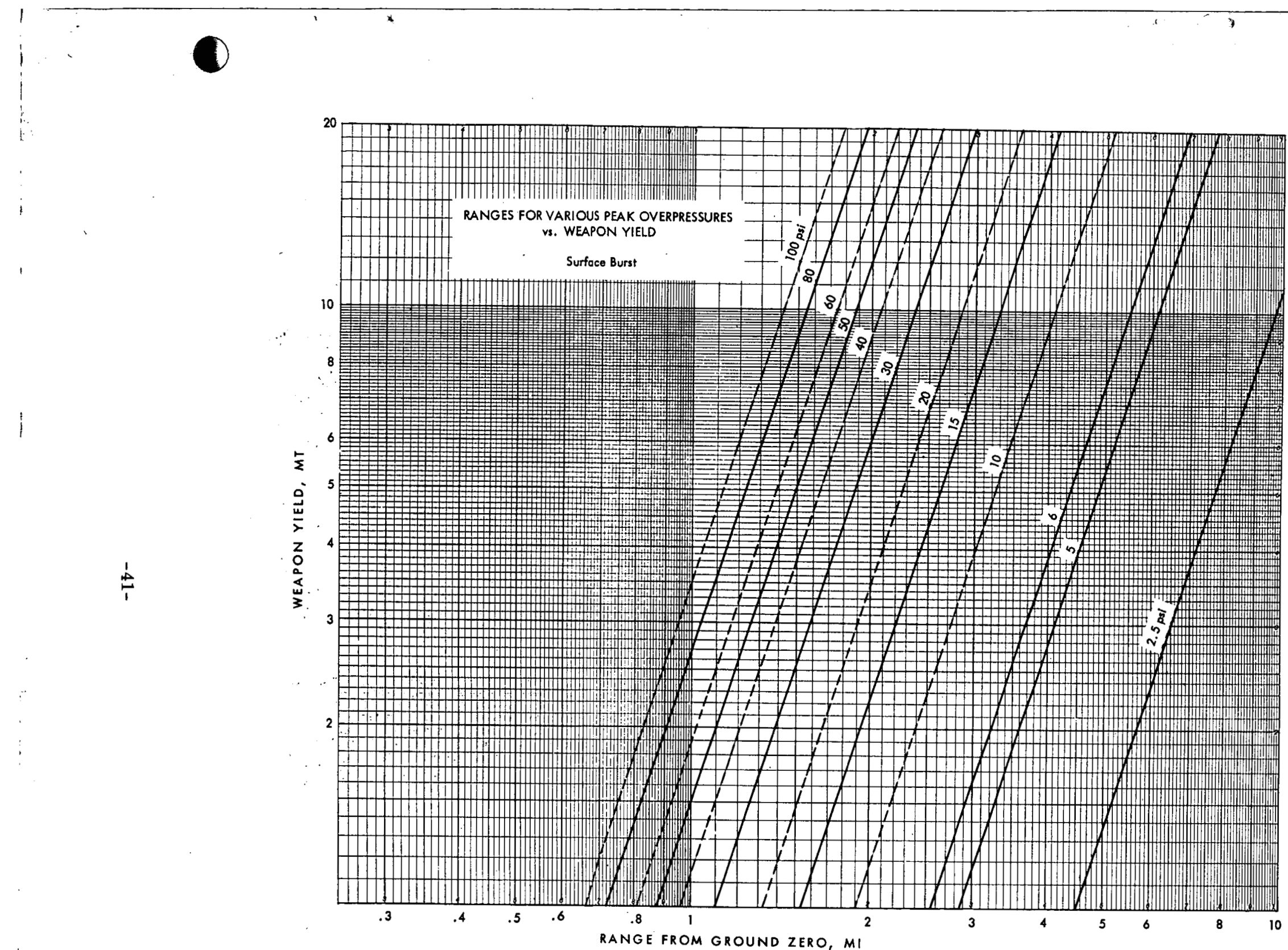

Figure 6. Ranges for various free-field incident overpressures for megaton explosions, surface burst at sea level. Data from The Effects of Nuclear Weapons (85). 
ESTIMATED SPATIAL EXTENT OF BIOLOGICAL DAMAGE DUE TO BLAST

Computed for I MT Surface Burst at Sea Level

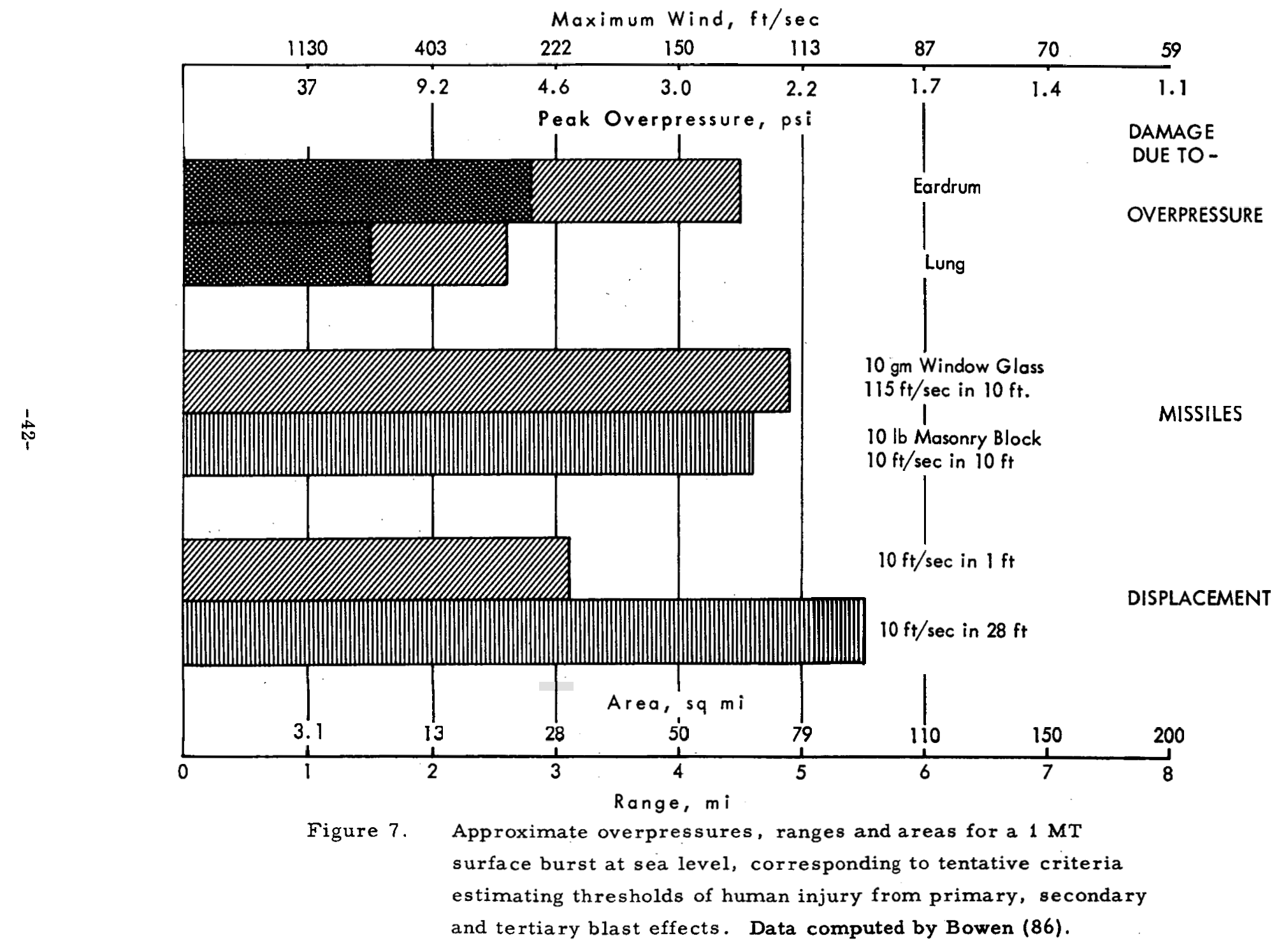


ESTIMATED SPATIAL EXTENT OF BIOLOGICAL DAMAGE DUE TO BLAST

Computed for 10 MT Surface Burst at Sea Level

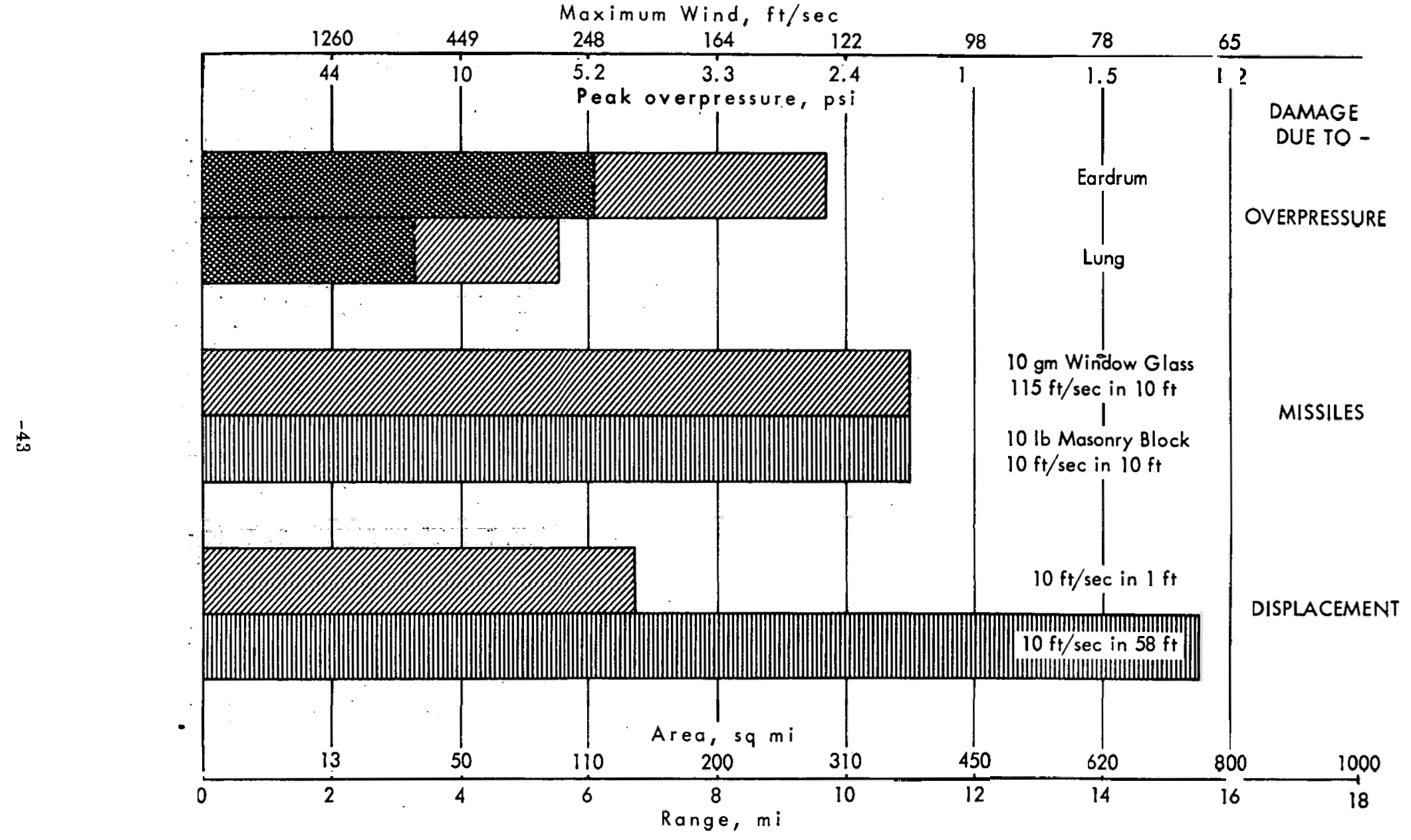

Figure 8. Approximate overpressures, ranges and areas for a $10 \mathrm{MT}$

surface burst at sea level corresponding to tentative criteria

estimating thresholds of human injury from primary, secondary

and tertiary blast effects. Data computed by Bowen (86). 


\section{REFERENCES}

1. C. S. White, T. L. Chiffelle, D.R.Richmond, W.H. Lockyear, I.G.Bowen, V.C.Goldizen, H.W.Merideth, D.E.Kilgore, B. B. Longwell, J.T.Parker, F.Sherping, and M.E. Cribb, "Biological Effects of Pressure Phenomena Occurring Inside Protective Shelters Following a Nuclear Detonation", Operation Teapot Report, WT-1179, October 28, 1957.

2. C.S. White, "Blast Biology - A Summary", a contribution to the Holifield Subcommittee Hearings, May 1, 1958. Published in Report of Hearings before a Subcommittee of the Committee on Government Operations, House of Representatives, Part I - Atomic Shelter Tests; Part II - Reorganization Plan No. 1 of 1958, pages 80-93. U.S. Government Printing Office, Washington, D.C., 1958.

3. T. L. Chiffelle, F.Sherping, V.C.Goldizen, and C.S.White, "A Study of the Tissue Response to Sterile Deposits of Particulate Material", Lovelace Foundation for Medical Education and Researck Report, AECU-3574, October 1957.

4. I.G.Bowen, D.R.Richmond, M.B.Wetherbe, and C.S. White, "Biological Effects of Blast from Bombs. Glass Fragments as Penetrating Missiles and Some of the Biological Implications of Glass Fragmented by Atomic Explosions", Lovelace Foundation for Medical Education and Regearch Report, AECU-3350, June 18, 1956.

5. Journee, "Relationship Between The Kinetic Energy of Bullets and The Seriousness of Wounds Which they may Inflict", Rev. D'Art., May 1907.

6. E. Newton Harvey, "The Mechanism of Wounding by High Velocity Missiles", Proc. Am. Philosoph. Soc., 92:294-304, 1948.

7. Theodor Benzinger, "Physiological Effects of Blast in Air and Water", Chap. XIV-B, pp. 1225-1259, German Aviation Medicine, World War II, Vol. II, U.S. Government Printing Office, Washington, 1950.

8. Car1-Johan Clemedson, "An Experimental Study on Air Blast Injuries", Acta Physio1. Scand., 18, Supp1. 61, Uppsala, 1949.

9. Hans Desaga, "Blast Injuries", Chap. XIV-D, pp: 1274-1293, German Aviation Medicine, World War II, Vol. II, U.S.Government Printing Office, Washington, 1950 .

10. D.R.Hooker, "Physiological Effects of Air Concussion", Am. J. Physiol., 67-68: 219-274, 1923-24.

11. National Research Council, Division of Medical Sciences, "Report on Blast Injuries", prepared by the Dffice of Medical Information, 11 June 1943.

12. Robert Rössle, "Pathology of Blast Effects", Chap. XIV-C, pp. 1260-1273, German Aviation Medicine, World War II, Vol. II, U.S.Government Printing Office, Washington, 1950. 
13. Edward L. Corey and Isidore Ger\$h, "Observations on the Effects of Air Blast on the Central Nervous System and Vigcera of Cats and Rabbits", Research Project X-219, Naval Medical Research Institute, National Naval Medical Center, Bethesda, Md., 24 June 1944.

14. P.L.Krohn, D. Whitteridge, and S.: Zuckerman, "Physiological Effects of Blast", Lancet, I: 252-258, 28 February 1942.

15. S. Zuckerman, "Experimental Study of Blast Injuries to the Lungs", Lancet, III: 219-238, 24 August 1940 .

16. Carl-Johan Clemedson, H. Hultman, and B. Grönberg, "Respiration and Pulmonary Gas Exchange in Blast Injury", J. Appl. Physiol., 6: 213-220, 1953.

17. Car1-Johan Clemeds on and H. Pettersson, "Genesis of Respiratory and Circulatory Changes in Blast Injury", Am. J. Physiol., 174: 316-320, 1953.

18. Car1-Johan Clemeds on and H. Hultman, "Air Embolism and the Cause of Death in Blast Injury", Military Surgeon, 114:424-437, 1954.

19. Arne Carlsten, Carl-johan Clemedson, and H. Hultman, "The Electrocardiogram of Rabbits in Blast Injury", Acta Physiol. Scand. , 33: 243-256, 1955.

20. Garl-Johan Clemedson and S.A.Granström, "Studies on the Genesis of Rib Markings' in Lung Blast Injury', Acta Physio1. Scand., 21:131-144, 1950.

21. Carl-Johan Clemedson, "Correlation Between Respiratory Phase and Extent of Lung Damage in Air Blast Injury"t, J. App1. Physio1,., 7: 38 -42, 1954.

22. S. Zuckerman, "The Problem of Blast Injuries", Proc. Roy. Sor. Med., 34: $171-188,1941$.

23. H. H.Sander and O.J.Birdsong, "Electrocardiograph Measurements at Operation Teapot", Tech. Memo 261-55-51, Sandia Corporation, Sandia Base, Albuque rque, New Mexico, 5 December 1955 .

24. Hjördis Celander, Car1-Johan Clemedson, U1f A. Ericsson, and H.Hultman, "A Study of the Relation Between the Diration of a Shock. Wave and the Severity of the Blast Injury. Produced by It', Acta Physiol. Scand., 33: 14-18, 1955.

25. Hjördis Celander, Carl-Johan Clemedson, Uif A. Ericsson, and H.Hultman, "The Use of a Compressed-air operated Shock Tube for Physiological Blast Research", Acta. Physiol. Scand, 32: 6-13, 1955.

26. H. Schardin,. "The Physical Principles of the Fffects of a Detonation", Chap. XIV-A, pp. 1207-1244, German Aviation Medicine, World War II, Vol. II, U.S: Government Printing Office, Washington, 1950.

27. Car1-Johan Clemedson, "Blast Injury", Physiol. Revs, 36: 336-354, 1956. 
28. A.H. Bebb, "Underwater Blast", British Report RNP. 53'/772, UWB 33, RNPL 2/53, September 1953.

29. L.M.Carlton, Jr., R.A.Rasmussen, and W.E.Adams, "Blast Injury of the Lung - Possible Explanation of Mechanism in Fatal Cases - An Experimental Study", Surgery, 17: 786-793, 1945.

30. R.D.Meade and R.T.Eckenrode, "Psychological and Physiological Effects of Gun Blast with Special Reference to Recoilless Rifles - A Preliminary Literature Survey", Human Engineering Report 7, Report R-1283 on Project TS4-4018, Pitman-Dun Laboratories, Frankford Arsenal, Philadelphia, September 1955.

31. A.J.Dziemian, F.W.Light, Jr., J.V.Michalski, and C.M.Herget, "Recoilless Rifle Backblast Danger Areas", Chemical Corps Medical Laboratory Report 72, Army Chemical Center, Md., July 1951.

32. E. L. Corey, 'Medical Aspects of Blast", U.S.Naval Med. Bull., 46: 623$652,1946$.

33. John F. Fulton, "Blast and Concussion in Present War", New Eng1. J. Med., 226: 1-8, 1942.

34. Benedict Cássen, Kathe rine Kistler, and Wanda Mankiewicz, "Some Effects of Air Blast on Mechanically Constrained Mice", J. Aviation Med., 23: $120-129,1952$.

35. Arturo Frisoli and Benedict Cassen, "A Study of Hemorrhagic Rib Markings Produced in Rats by Air Blast". J. Aviation Med., 21:510-513, 1950.

36. Carl-Johän Clemedson, L. Deffet, R. Rucquoi Fornaeus, and P. Van de Wouwer, "Highspeed Radiographic Visualization of a High-explosive Shock Wave in Muscular Tissue", J. Appl. Physiol. 7:604-608, May 1955.

37. R.B.Fisher, P.L.Krohn, and S.Zuckerman, "The Relationship Between Body Size and the Lethal Effects of Blast", Ministry of Home Security Report R.D. 284, dated 10.12,41.

38. R.B.Fisher, P.L.Krohn, and S. Zuckerman, "The Relationship Between Body Size and the Lethal Effects of Blast", Ministry of Home Security Report B.P.C. 146/W.S. 11, dated 23.11.41.

39. V. Blocker and T.G.Blocker, "The Texas City Disaster - A Survey of 3, 000. Casuaities", Am. Jour. Surg., LXXVII: 756-771, 1949.

40. Ruskin; A.; Beard, O.W., Schaffer, R. L., "Blast Hypertension", Am. Jour. Med., IV: $228 \cdots 236,1948$.

41. A. Ruskin, and O.W.Beard, "The Texas City Disaster-Cardiovascular Studies,"with Follow-up Results", Texas Reports" on Biolog. and Med,, 6: 2,43-259: 1948 . 
42. G.S.McReynolds, F.R. Guilford, and G.R. Chase, "Blast Injuries to the Ear", Arch. Otolaryng. , 50: 1-8, 1949.

43. S. Zuckerman, "Rupture of the Ear Drums by Blast", Ministry of Home Security Report B.P.C. 148/W.S. 13, Oxford, England, 22 Nov. 1941.

44. W.E. Clapper, J.E.Roberts and G.H.Meade, "Radiation Effects on Pneumococcal. Infection Produced by Subcutaneous Injections into White Mice", Proc.Soc. Dxper.Biol. and Med., 86: 420-422, 1954.

45. W. E. Clapper and G.H. Meade, "Radiation Effects on Pneumococcal Infection Produced by Subcutaneous Injections into White Mice", Lovelace Foundation for Medical Education and Research Report, AECU-3267, 1957.

46. W.E. Clapper and G.H. Meade, "The Effect of Foreign Body Particles on Infections in Mice", Lovelace Foundation for Medical Education and Research Report, AECU-3272, August 15, 1955.

47. I.G.Bowen, A.F.Streh]er, and M.B.Wetherbe, "Distribution and Density of Missiles from Nuclear Explosions", Operation Teapot Report, WT-1168, December 14, 1956.

48. D. R. Richmond, M.B.Wetherbe, R.V.Taborelli, T. L. Chiffelle, and C.S. White, "The Biologic Response to Overpressure. I. Effects on Dogs of Five to Ten-second Duration Overpressures Having Various Times of Pressure Rise", J. Aviation Med., 28: 447-460, 1957.

49. D.R.Richmond, R.V.Taborell, T.L.Chiffelle, V. C.Goldizen, J.D. Ward, M.B.Wetherbe, V.R. Clare, and R.T.Sanchez, "Blast Biology-A Study of the Primary and Tertiary Effects of Blast in Open Underground Protective Shelters", Operation Plumbbob Report, ITR-1467, November 29, 1957.

50. D.R.Richmond, R.V.Taborelli, I.G.Bowen, T. L. Chiffelle, F.G.Hirsch, B.B. Longwell, J.G.Riley, C.S. White, F.Sherping, V.C.Goldizen, J.D. Ward, M.B.Wetherbe, V.R. Clare, M.L.Kuhn, and R:T.Sanchez, "Blast Biology - A Study of the Primary and Tertiary Bffects of Blast in Open Underground Protective SheIters", Operatión Plumbbob Report, WT-1467, in the press.

51. R, V.Taborelli and I.G.Bowen, "Tertiary Effects of Blast - Displacement", Operation Plumbbob Report, ITR-1469, December 20, 1957.

52. R. V.Taborelli, I.G.Bowen and E.R: Fletcher, "Tertiary Effects of Blast Displacement", Operation Plumbbob Report, WT-1469, in the press.

53. V.C.Goldizen, D.R.RJ.ehmond, and T.L.Chiffelle, "Missile Studies with a Biological Target"!, Operation Plumbbob Report, ITR-1470, November 29. 1957.

54. C.S.White, M.B.Wetherbe, and V.C.Goldizen, "The Internal Environment of Underground Structures Subjected to Nuclear Blast. I. The Occurrence 
of Dust", Operation Plumbbob Report, ITR-1447, November 22, 1957.

55. D.R. Richmond and R.V. Taborelli, "Some Results of a Shock Tube for Biomedical Investigation", pp. 56-69 of Proceedings of Second Shock Tube Symposium, 5-6 March 1958, SWR-TM-58-3, Hqs. Air Force Special Weapons Center, ARDC, Kirtland Air Force Base, New Mexico.

56. D.R.Richmond, R.V.Taborelli, F.Sherping, M.B.Wetherbe, R.T. Sanchez, V.C.Goldizen, and C.S.White, "Shock Tube Studies of the Effects of Sharp-Rising, Long Duration Ove rpressures on Biological Systems", presented at the Third Shock Tube Symposium, sponsored by the Air Force Special Weapons Center, Kirtland Air Force Base, New Mexico, and held at Fort Monroe, Va,, March 9-11, 1959 (to be published).

57. D.R.Richmond, Atomic Energy Project, Lovelace Foundation, Albuquerque, New Mexico, personal communication.

58. E.G.Butler, W.O.Puckett, E. Newton Harvey and J.H.McMillen, "Experiments on Head Wounding by High Velocity Missiles", J. Neurosurg., II: $358-363,1945$.

59. W.O.Puckett, W.D.McElroy, and E.Newton Harvey, "Studies on Wounds of the Abdomen and Thorax Produced by High Velocity Missiles", The Military Surgeon, $98: 427-439,1946$.

60. E.Newton Harvey, Arthur H. Whiteley, H. Grundfest, and J.H.McMillen, "Piezoelectric Crystal Measurements of Pressure Changes in the Abdomen of Deeply Anaesthetized Animals During Passage of a High Velocity Missile", The Military Surgeon, 98:509-528, 1946.

61. E.Newton Harvey, E.G.Butler, J.H.McMillen, and W.O.Puckett, "Mechanism of Wounding", War Med., 8: $91-104,1945$.

62. E.Newton Harvey, I. M.Korr, G.Oster, and J.H.McMillen, "Secondary Damage in Wounding Due to Pressure Changes Accompanying the Passage of High Velocity Missiles", Surgery, 21:218-239, 1947.

63. R.H.Holmes, "Wound Ballistics and Body Armor", JAMA, 150: 73-78, 1952.

64. J.P.Henry, C.S.White, I. G.Bowen, T. L.Chiffelle, W.H. Lockyear, D. R. Richmond, and V.C.Goldizen, Unpublished data, Atomic Energy Project, Lovelace Foundation, Albuque rque, New Mexico.

65. S. Zuckerman, "The Wounding Power of Debris", Ministry of Home Security, Report RC 423, Oxford, England, 7 July 1944.

66. J.H.McMillen and E. Newton Harvey, "A Spark Shadowgraphic Study of Body Waves in Water", J. App1. Physics, 17:541-555, 1946.

67. E.S.Gurdjian, H.R. Lissner, F.R. Latimer, B.F.Haddad, and J E.Webster, "Quantitative Determination of Acceleration and Intracranial Pressure in 
Experimental Head Injury - Preliminary Report", Neurology, Vol. 3 , $417-423,1953$.

68. Robert H. Pudenz and C. Hunter Shelden, "The Lucite Calvarium - A Method for Direct Observation of the Brain. II. Cranial Trauma and Brain Movement", J. Neurosurg. , III: 487-505, 1946.

69. Hugh DeHaven, "Mechanics of Injury Under Force Conditions", Mech. Engineer., 66: 264-268, 1944.

70. E.S.Gurdjian, J.E.Webster, and H.I. Lissner, "Studies on Skull Fracture with Particular Reference to Engineering Factors", Am. J. Surg., 78: $736-742,1949$.

71. W.A.Haddon, and R.A.McFarland, "A Survey of Present Knowledge of the Physical Thresholds of Human Head Injury from the Engineering Standpoint", preprint, undated, courtesy of the authors.

72. Külbs, "Lunge und Trauma", Arch. Pathol. expt1., 62:39-46, 1909.

73. Roy Greening, Adele Kynette and P.J.Hodes, "Unusual Pulmonary Changes Secondary to Chest Trauma", Am. J. Roentg., Rad. Ther. and Nuc. Med., IXXVII: 1059-1065, 1957.

74. W.K.Stewart, K.E.Spells, and J.A.Armstrong, "Lung Injury by Impact with a Water Surface", Nature, 175:504-505, 1955.

75. J.A.Armstrong, D.I. Fryer, W.K. Stewart, and H.E.Whittingham, "Interpretation of Injuries in the Comet Aircraft Disasters - An Experimental Approach", Lancet, I: 1135-1143, 1955.

76. A.N.Black, D.G. Christopherson, and S. Zuckerman, "Fractures of the Head and Feet", Ministry of Home Security, Report RC.334, Oxford, England, 12 August 1942.

77. S. Zuckerman, "The Effects of Direct Concussion on Monkeys in Underground Shelters", Ministry of Home Security, Report RC.65, Oxford, England, December 1939.

78. S. Zuckerman and A.N.Black, "The Effect of Impacts on the Head and Back of Monkeys", Ministry of Home Security, Report R. C. 124, Oxford, England, 26 August 1940.

79. R.H.Draeger, J.S.Barr, J.Y. Dunbar, W.W.Sager, and M.C.Shelesnyak, "A Study of Personnel Injury by 'Solid Blast' and the Design and Evaluation of Protective Devices", Naval Medical Research Institute Report No. 1, Project X-517, Bethesda; Md., 30 March 1945.

80. Hans Desaga, "Experimental Investigations of the Action of Dust", Chap. XIII-B, pp. 1188-1203, German Aviation Medicine,World War II, Vol. II, U.S.Government Printing Office, Washington, 1950. 
81. George Armistead, Jr., "The Ship Explosions at Texas City, Texas, on' April 16 and 17, 1947, and Their Results", Engineering Consultants Report to John G. Simonds and Company, Inc., Oil Insurance Underwriters, New York City, Washington, D.C., June 1, 1947.

82. C. S. White and I. G. Bowen, "Comparative Effects Data of Biological Interest"', First Draft - corrected and expanded, AEC Project Report, 10 April 1959.

83. Teofil Zalewski, "Experimentelle Untersuchungen über die Resistenzfåhigkeit des Trommelfells", Z. Ohrenheilk, 52: 109-128, 1906。

84. Siegfried Ruff, "Brief Acceleration: Less Than One Second", Chap. VI-C, pp. 584-597, German Aviation Medicine, World War II, Vol. I, U. S. Government Printing Office, Washington, D.C., 1950.

85. Armed Forces Special Weapons Project, Department of Defense, "The Effects of Nuclear Weapons," edited by Samuel Glasstone, U. S. Government Printing Office, Washington 25, D.C., June 1957.

86. I. G. Bowen, Missiles Secondary to Nuclear Blast, Report on Project 33. 2, Operation Plumbbob Report, WT-1468, Lovelace Foundation for Medical Education and Research, Albuquerque, New Mexico - in preparation. 